\title{
8. THE EASTERN WALVIS RIDGE AND ADJACENT BASINS (SOUTH ATLANTIC): MORPHOLOGY, STRATIGRAPHY, AND STRUCTURAL EVOLUTION IN LIGHT OF THE RESULTS OF LEGS 40 AND $75^{1}$
}

\author{
Jean-Claude Sibuet, Centre Océanologique de Bretagne, B.P. 337, 29273 Brest Cedex, France \\ William W. Hay, Museum, University of Colorado, Boulder, Colorado \\ Annick Prunier, Snea (P), Tour Générale, La Défense 9, 92088 Puteaux, France \\ Lucian Montadert, Institut Français du Pétrole, 1-4 avenue de Bois-Préau, 92506 Rueil Malnaison Cedex, France \\ and \\ Karl Hinz and Jurgen Fritsch, Bundesanstalt für Geowissenschaften und Rohstoffe, Stilleweg 2, Postfach 5101 53, \\ D-3000 Hannover 51, Federal Republic of Germany
}

\begin{abstract}
Data from gravimetric and magnetic surveys and multichannel processed seismic profiles correlated with DSDP data obtained by the Glomar Challenger at Sites 530,531, 532/362, and 363 (Legs 40 and 75) permit definition of the regional stratigraphy and structural evolution of the Walvis Ridge and adjacent basins. The easternmost Walvis Ridge is probably continental crust thinned at a rifting center along the trend of the Namibian and Angolan margin. Oceanward dipping reflectors within the western part of this thinned continental crust are probably volcanics with some sedimentary interbeds. The central plateau of the eastern Walvis Ridge is interpreted as abnormal ocean crust emplaced near sea level. The western end of the eastern Walvis Ridge adjoins the N-S segment of the ridge and was formed after a late Aptian-early Albian eastward jump of the spreading center north of the ridge, translating the salt deposits to the South American side of the young ocean basin.
\end{abstract}

\section{INTRODUCTION}

The Walvis Ridge is an aseismic ridge more than $3,000 \mathrm{~km}$ long extending from the Mid-Atlantic Ridge to the African coast. It is divided into three sections: (1) the eastern (Frio) segment, extending from Cape Frio to $6^{\circ} \mathrm{E}$, is $600 \mathrm{~km}$ long and consists of two east-northeast west-southwest trending basement ridges enclosing a relatively large sedimentary basin; (2) a central segment, $500 \mathrm{~km}$ long, oriented roughly north-south; and (3) a western section, consisting mainly of seamounts, which connect the Walvis Ridge to the Mid-Atlantic Ridge in the vicinity of Tristan de Cunha and Gough Islands.

The relative tightness of the fit of continents around the South Atlantic Ocean (e.g., Bullard et al., 1965) makes it seem reasonable to assume that the largest portion of the Walvis Ridge should be of oceanic origin, although van der Linden (1980) argued that it is a continental sliver. Hypotheses concerning the formation of the ridge in the oceanic context can be divided in two groups:

1) Formation synchronous with the opening of the South Atlantic and related to mantle "hot spots" (Wilson, 1965; Dietz and Holden, 1970; Morgan, 1971, 1972), or to transform directions and marginal offsets (Le Pichon and Hayes, 1971; Francheteau and Le Pichon, 1972), or to a combination of both (Goslin and Sibuet, 1975); and

2) Formation after and unrelated to the opening of the South Atlantic, involving major uplift (Ewing et al., 1966; Maxwell et al., 1970).

\footnotetext{
${ }^{1}$ Hay, William W., and Sibuet, Jean-Claude, et al., Init. Repts DSDP, 75: Washington (U.S. Govt. Printing Office).
}

This chapter combines the results from recent multichannel seismic surveys and DSDP holes drilled during Legs 40 (Bolli, Ryan et al., 1978) and 75 (this volume), and explores the problem of the origin, formation, and evolution of the Walvis Ridge. It demonstrates that at Site 530 in the Angola Basin, the ridge plays a double role for sedimentation, acting as both a dam to oceanographic circulation and a source of turbidites, debris flows, and basalt pebbles.

\section{MORPHOLOGY}

A new Mercator bathymetric map in corrected meters (Matthews, 1939) has been prepared for the area from $2^{\circ} \mathrm{E}$ to $15^{\circ} \mathrm{E}$ and from $15^{\circ} \mathrm{S}$ to $23^{\circ} \mathrm{S}$ (Fig. 1) using published information from Simpson (1981), Goslin et al. (1974), Barnaby (1974), Heezen et al. (1978), and the GEBCO chart as well as unpublished data from the Centre Océanologique de Bretagne (C.O.B.), the Institut Français du Pétrole (I.F.P.), and the Bundesanstalt für Geowissenshaften und Rohstoffe (B.G.R.). The relative closeness of tracklines gives substantially better morphologic control than was available previously.

The eastern segment of the Walvis Ridge, oriented ENE-WSW, is a linear structure of relatively constant width $(130 \mathrm{~km})$ located at a mean depth of $2,500 \mathrm{~m}$; it is about 2,500 $\mathrm{m}$ higher than the adjacent Angola Basin floor. The connection of the ridge with the continent corresponds to a spur of the continental margin roughly delimited by the $2,000 \mathrm{~m}$ isobath. The spur forms structural provinces 1 and 2 of the eastern segment of the ridge; these two provinces are separated by a basement depression which has no surface expression and which will be discussed later. Between $8^{\circ} \mathrm{E}$ and $10^{\circ} \mathrm{E}$, the northern flank of the ridge is rectilinear and abrupt, 


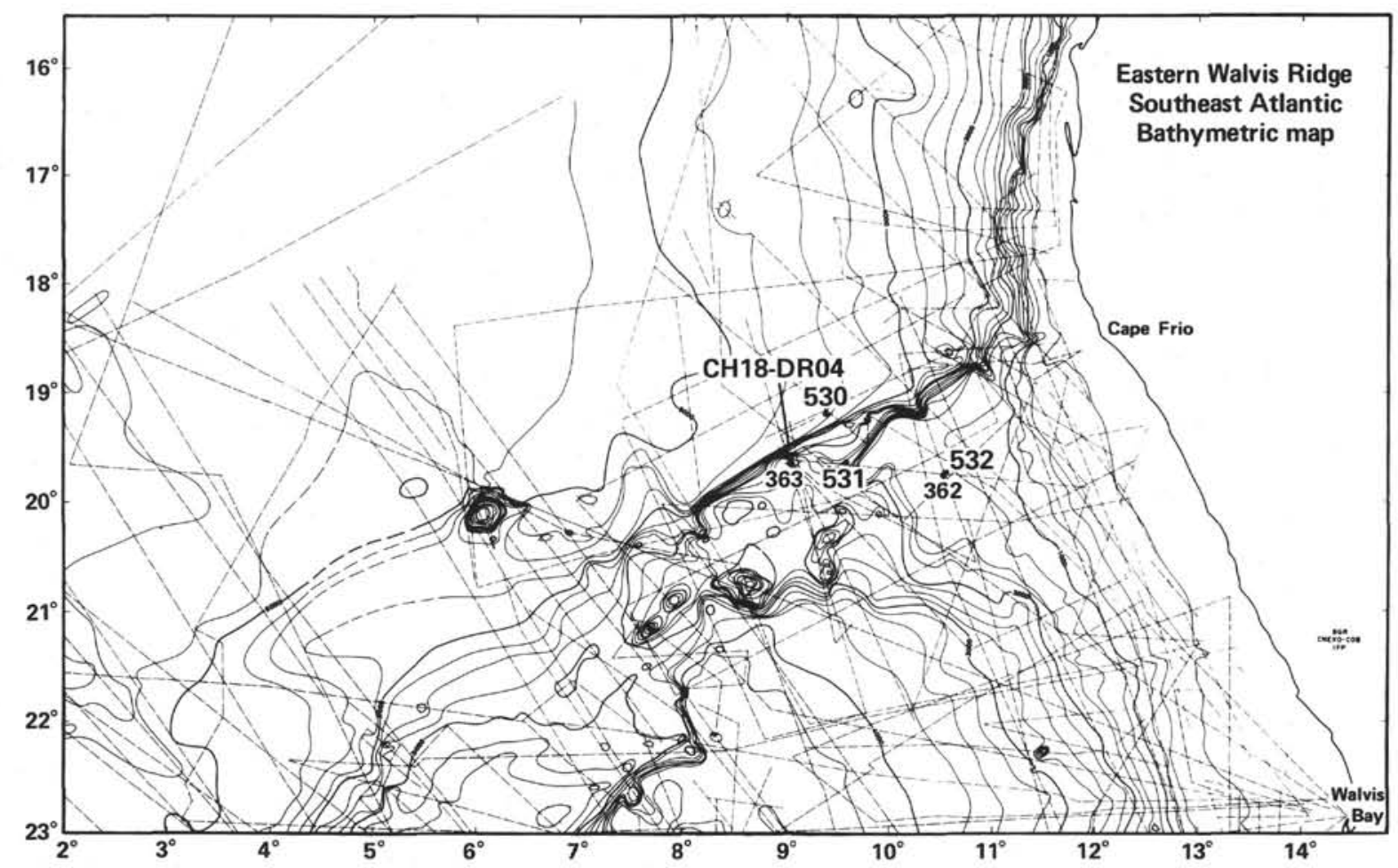

Figure 1. Bathymetric map of the eastern Walvis Ridge in Mercator projection with the trackline control in dashed lines. Depths are in corrected $\mathrm{m}$ (Matthews, 1939). Contour interval is $250 \mathrm{~m}$. Position of CH 18-DR04 dredge and DSDP drilled sites is shown.

characterized by a regular slope of about 10 degrees down into the Angola Basin. Between $8.5^{\circ} \mathrm{E}$ and $9.5^{\circ} \mathrm{E}$, on Cape Basin side, the slope is irregular and marked by the presence of several features having large relief. Between the two flanks of the ridge, from $8^{\circ} \mathrm{E}$ and $10^{\circ} \mathrm{E}$ and from $20^{\circ} \mathrm{S}$ and $21^{\circ} \mathrm{S}$, the ridge crest forms a terrace tilted slightly towards the north. The western portion of the eastern Walvis Ridge is bounded on the west by the north-south ridge segment (which includes the Valdivia Bank to the south of the area of the new map).

The depth in the Angola Basin, north of the ridge, is $5 \mathrm{~km}$, while to the south of the ridge, in the Cape Basin, the depth is only $4 \mathrm{~km}$. The change in gradient at the base of the continental slope in the Angola Basin is about $200 \mathrm{~km}$ east of that in the Cape Basin. These differences are the result of greater thickness of sediments in the Cape Basin than in the Angola Basin. From inspection of the morphology (Fig. 1) it is evident that downslope sediment transport from the upper Walvis Ridge to the adjacent basins would be (1) into the Cape Basin from structural provinces 1 and 2, which are bordered on the west by the $2,000 \mathrm{~m}$ isobath and characterized by high accumulation rates (DSDP Sites 362 and 532), and (2) into the Angola Basin from structural province 3, which forms the middle part of the eastern segment of the ridge, located between $8^{\circ} \mathrm{E}$ and $10^{\circ} \mathrm{E}$, and which is characterized by lower accumulation rates. Unfortunately the bathymetric and seismic coverage are still inadequate to demonstrate the existence of channels through the northern flank of the ridge which would facilitate the transport of sediment into the Angola Basin.

\section{STRATIGRAPHY}

This stratigraphic interpretation utilizes two correlated sources of data. The first source of information is the acoustic stratigraphy indicated by the seismic profiles from the eastern Walvis Ridge and adjacent basin areas (Fig. 2). The second source is information from R/V Jean Charcot dredges (Pastouret and Goslin, 1974; Hékinian, 1972) and core samples from DSDP Sites 362, 363 (Leg 40, Bolli, Ryan et al., 1978) 530, 531, and 532 (Leg 75, this volume).

When investigations were initiated in this area for IPOD, published information was scarce (Simpson, 1970; Goslin et al., 1974; Barnaby, 1974; Goslin and Sibuet, 1975; Emery et al., 1975), and only single channel seismic data were available. Three institutions (C.O.B., I.F.P., and B.G.R.) interested in the proposed program carried out two regional multichannel seismic surveys in $1977(5,000 \mathrm{~km}$ with the R/V Résolution and in 1978 $(5,000 \mathrm{~km}$ with the R/V Explora). The University of Texas undertook the final site surveys in 1979 (Musgrove and Austin, this volume) (Fig. 2).

Seismic stratigraphic techniques of analysis (Payton, 1977) were used in this study. Seismic discontinuities, identified by the lateral terminations of reflections, were recognized and traced on all the processed French and German seismic records. Three major discontinuities above basement separate four major seismic units of about equal thickness. These units are "mega-sequences" in the terminology of Vail et al. (1977). The identification of these discontinuities and seismic units was 


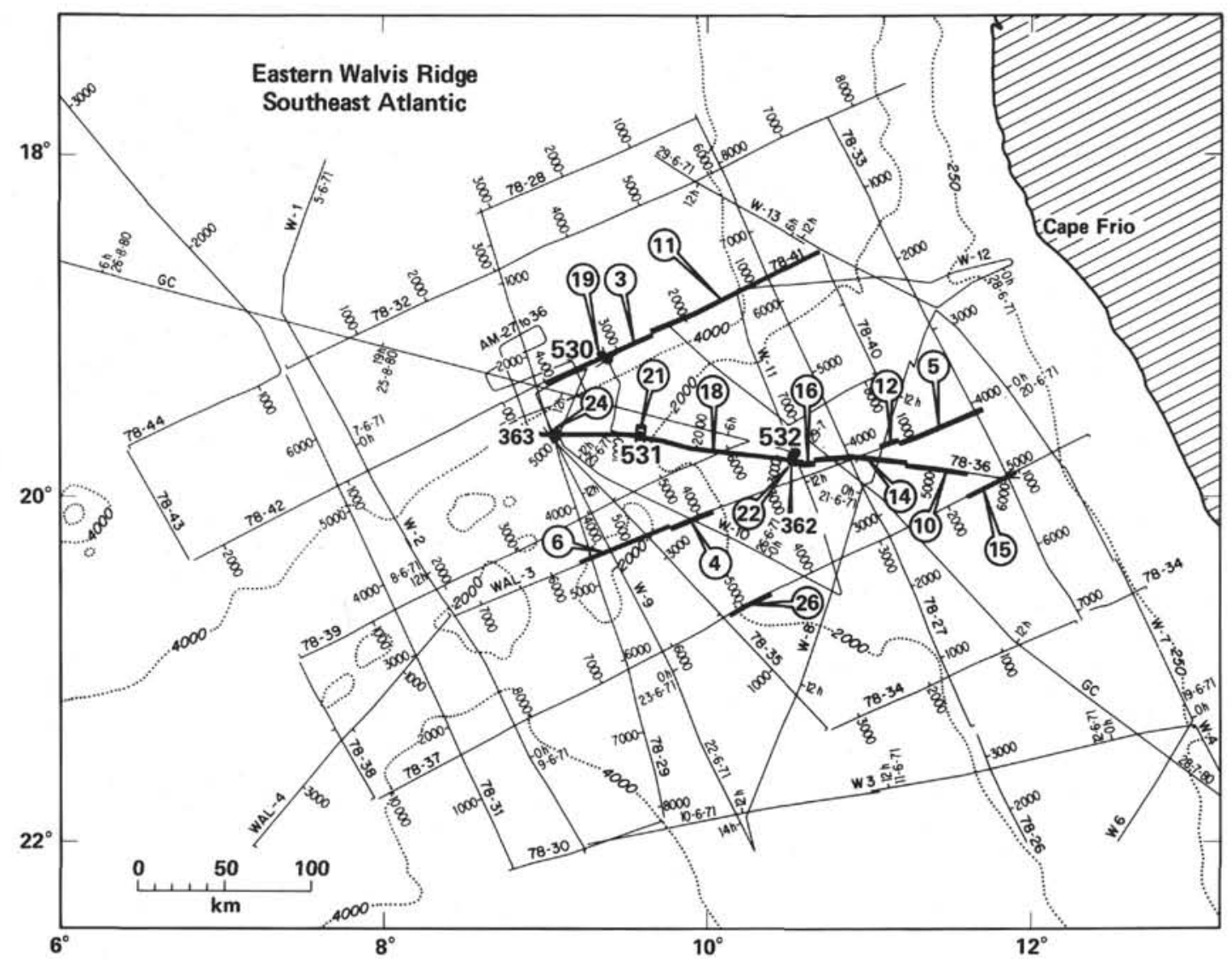

Figure 2. Index map of seismic lines used in this study. Heavy lines correspond to seismic sections illustrated in this chapter; numbers in circles refer to the figure number in this chapter. DSDP sites are indicated by bold numbers.

then extended to previous data and to the University of Texas seismic profiles. After drilling, the basement and sedimentary formations were calibrated using data from DSDP Legs 40 and 75.

\section{Acoustic Basement}

In the deep basins, the acoustic basement corresponds to a large contrast in acoustic impedance and is highly diffractive because of its roughness. Computed velocities of $5.3 \mathrm{~km} / \mathrm{s}$ from processed seismic profiles (e.g., Fig. 3) confirm the basaltic nature of the basement drilled at Site 530 where lab measurements give velocities for these basalts ranging from 4.7 to $5.0 \mathrm{~km} / \mathrm{s}$ (Boyce, this volume). The irregular character of the acoustic basement in the vicinity of Site 530 is clearly demonstrated by the University of Texas survey, which shows ridges and troughs roughly perpendicular to the strike of the northern flank of the Walvis Ridge on which are superimposed local features such as conical peaks or depressions (Musgrove and Austin, this volume). A Seabeam profile run in 1979 by the R/V Jean Charcot through the Angola Basin, northwest of Site 530 , confirms the existence of this general system of ridges and troughs parallel to the rift direction and shows that they are cut only by the fracture zones. Consequently, it seems that at Site $\mathbf{5 3 0}$ the basement is typically oceanic.

On the Walvis Ridge, the basement character defined on processed data (24-fold stack with variable filtering and deconvolution), can be related to one of the three following types:

1) The first type of acoustic basement produces a series of high amplitude and low frequency diffractions of the sort characteristic of rough basement of probably basaltic origin; the seismic character is similar to that of the oceanic basement (example in Fig. 4).

2) The second type of acoustic basement lacks the diffracting character but appears to be a major discontinuity below which coherent reflections appear as deep as 2 seconds double travel line (sdtt) below it. These deep basement reflectors are subparallel, forming westward (oceanward) dipping wedges (see examples in Figs. 5 and 18).

3) The third type of acoustic basement is distinguished by a flat, generally horizontal discontinuity. Deep basement reflectors also appear below this discontinuity, but it is not always possible to determine whether they dip predominantly oceanwards (example in Fig. 6).

Using all available data, the acoustic basement surfaces thus defined have been mapped in sdtt (Fig. 7) and, using only the B.G.R. profiles, in km (Fig. 8). The map of the depth to basement in kilometers (Fig. 8) was prepared using velocity analysis of profile B.G.R. 39, which was run along the top of the ridge (Fig. 2). A major change in velocities occurs at the lower Oligocene discontinuity as identified by correlation with Site 362 . Depths, therefore, have been calculated using a simple two-layer velocity model (Prunier, 1980). The main to- 

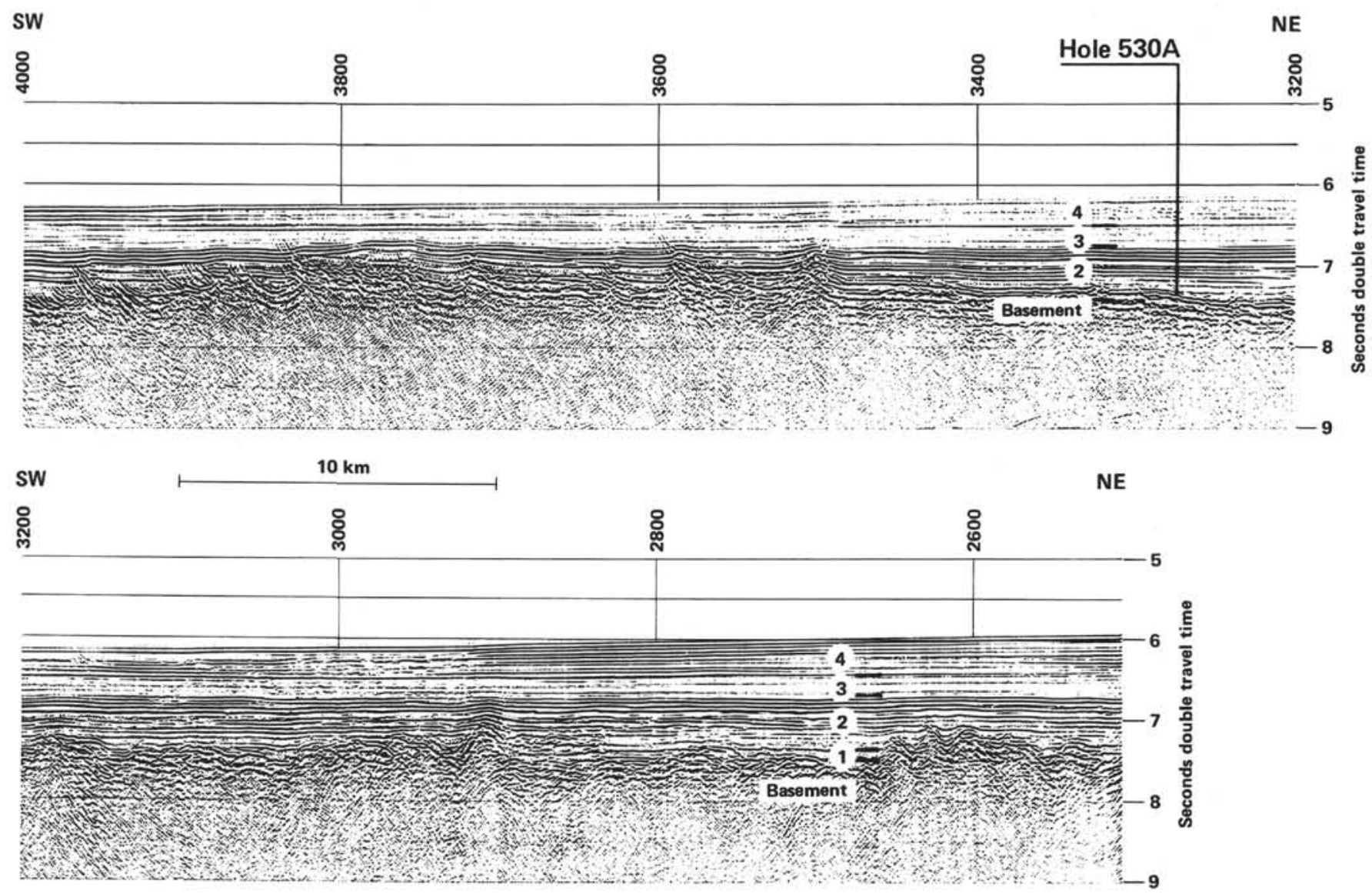

Figure 3. BGR-41 migrated seismic section in the Angola Basin near Site 530. Location in Figure 2. The main acoustic units are identified as follows: Unit 1, older than Cenomanian; Unit 2, Cenomanian to early Oligocene; Unit 3, early Oligocene to early late Miocene; Unit 4, early late Miocene to present.
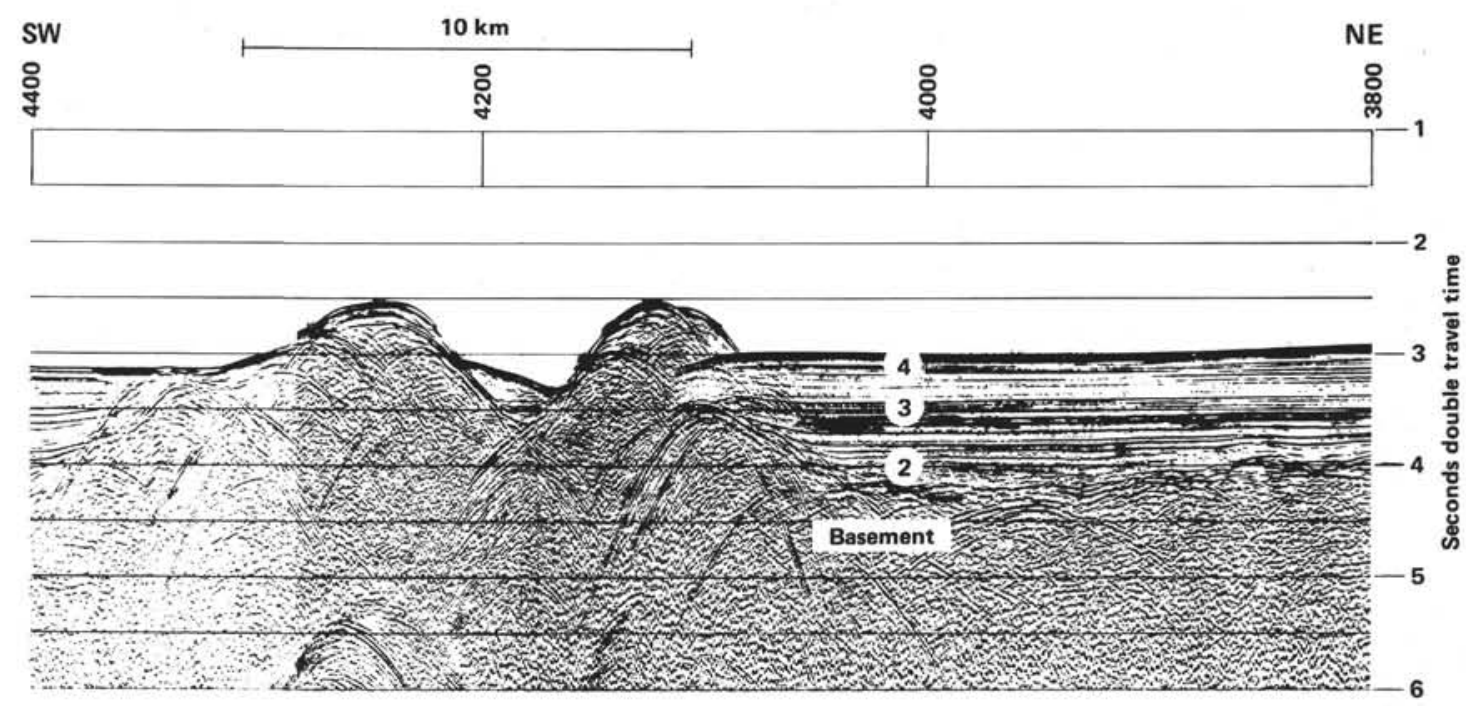

Figure 4. Processed seismic profile Wal 3 on the eastern Walvis Ridge. Location in Figure 2. The basement of probable basaltic origin is marked by high amplitude, low frequency diffraction figures. The main acoustic units present are identified as follows: Unit 2, Cenomanian to early Oligocene; Unit 3, early Oligocene to early late Miocene; Unit 4, early late Miocene to present. 

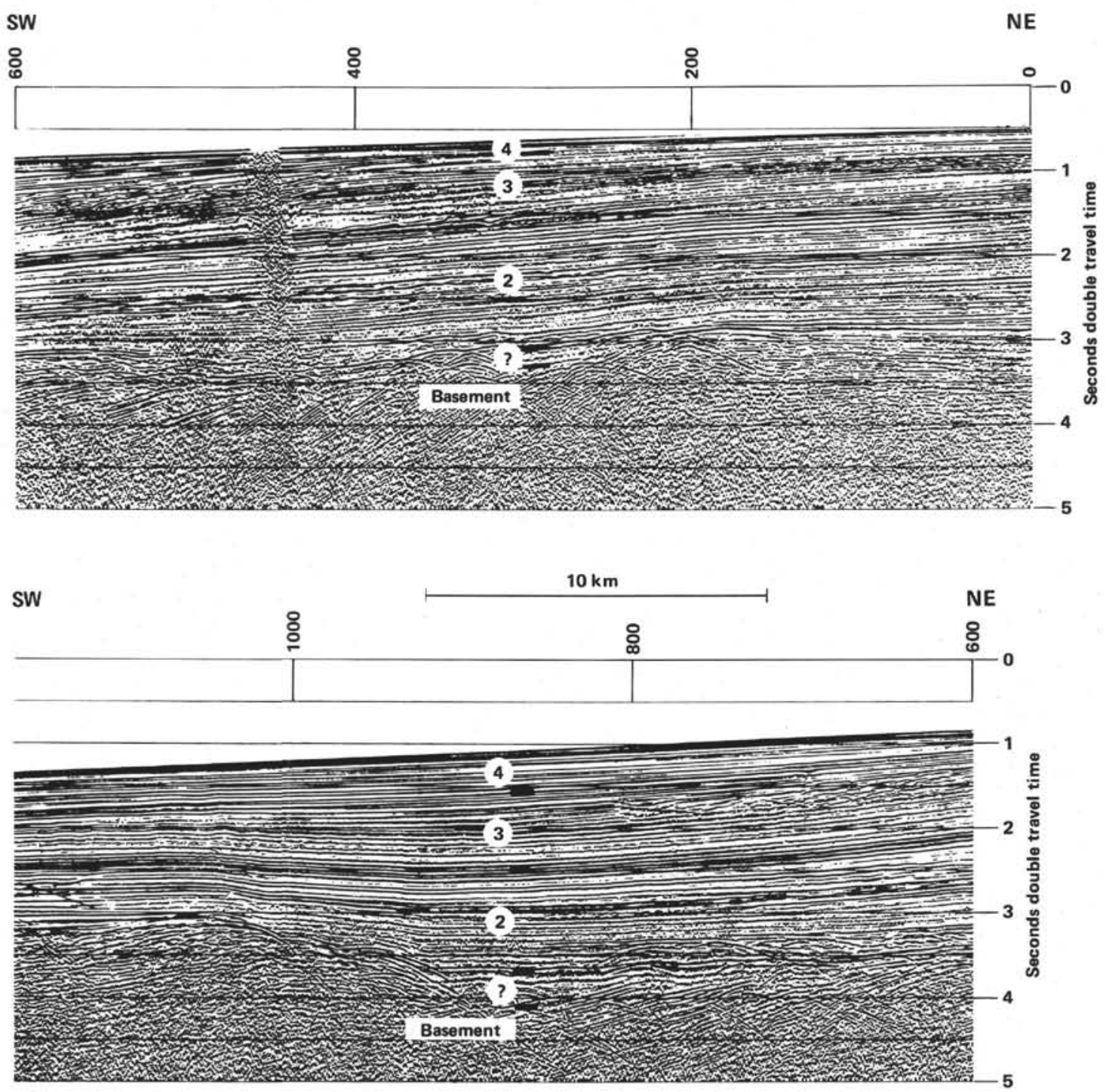

Figure 5. Processed seismic profile Wal 3 on the eastern Walvis Ridge. Location in Figure 2. Example of oceanwards dipping reflectors within the basement. The main acoustic units are identified: Unit 1, older than Cenomanian may be present and is indicated by question marks; Unit 2, Cenomanian to early Oligocene; Unit 3, early Oligocene to early late Miocene; Unit 4, early late Miocene to present.

pographic features are also evident on the basement maps, but as a result of the difference in the thickness of sediments north and south of the ridge, the flanks of the Walvis Ridge appear to be more symmetrical than on the bathymetric map. The major structural provinces identified on the ridge ( 1 to 4 ) are clearly delineated on these maps.

Over all of provinces 1 and 2, except the area near the continent where no seismic data are available, basement lies at approximately $4 \mathrm{~km}$ and is marked by several slight depressions oriented roughly north-south.

\section{Total Thickness of Sediments}

A time isopach map of the sedimentary cover above basement (Fig. 9) was prepared using all available data in the area between $7^{\circ} \mathrm{E}$ to $13^{\circ} \mathrm{E}$ and between $17^{\circ} \mathrm{S}$ to $23^{\circ} \mathrm{S}$. The sediment thickness decreases from east to west. Sedimentary basins are located between the two crests of the ridge at distances up to $500 \mathrm{~km}$ from the coast. No preferred direction of sediment input can be established. On the continental margin adjacent to the ridge, there is no trend of the isopachs which would suggest the presence of a southward-flowing current supplying the ridge depressions with sediment as suggested by Goslin et al. (1974). On the Angola margin a $3.5 \mathrm{sdtt}$ deep basin abuts the ridge and extends southwestward along its northern flank, suggesting a southwestward transport of turbidites or a sediment source from the easternmost Walvis Ridge. In any case, the role of the Walvis Ridge as a dam for sediment transport (e.g., Goslin et al., 1974; Barnaby, 1974) is confirmed by the presence of the northern ridge, extending into the continental margin and barely covered by sediments (Figs. 7, 8 , and 9).

\section{Acoustic Stratigraphy}

The northern ridge with its thin sediment cover and the steep Angola continental margin with many discon- 

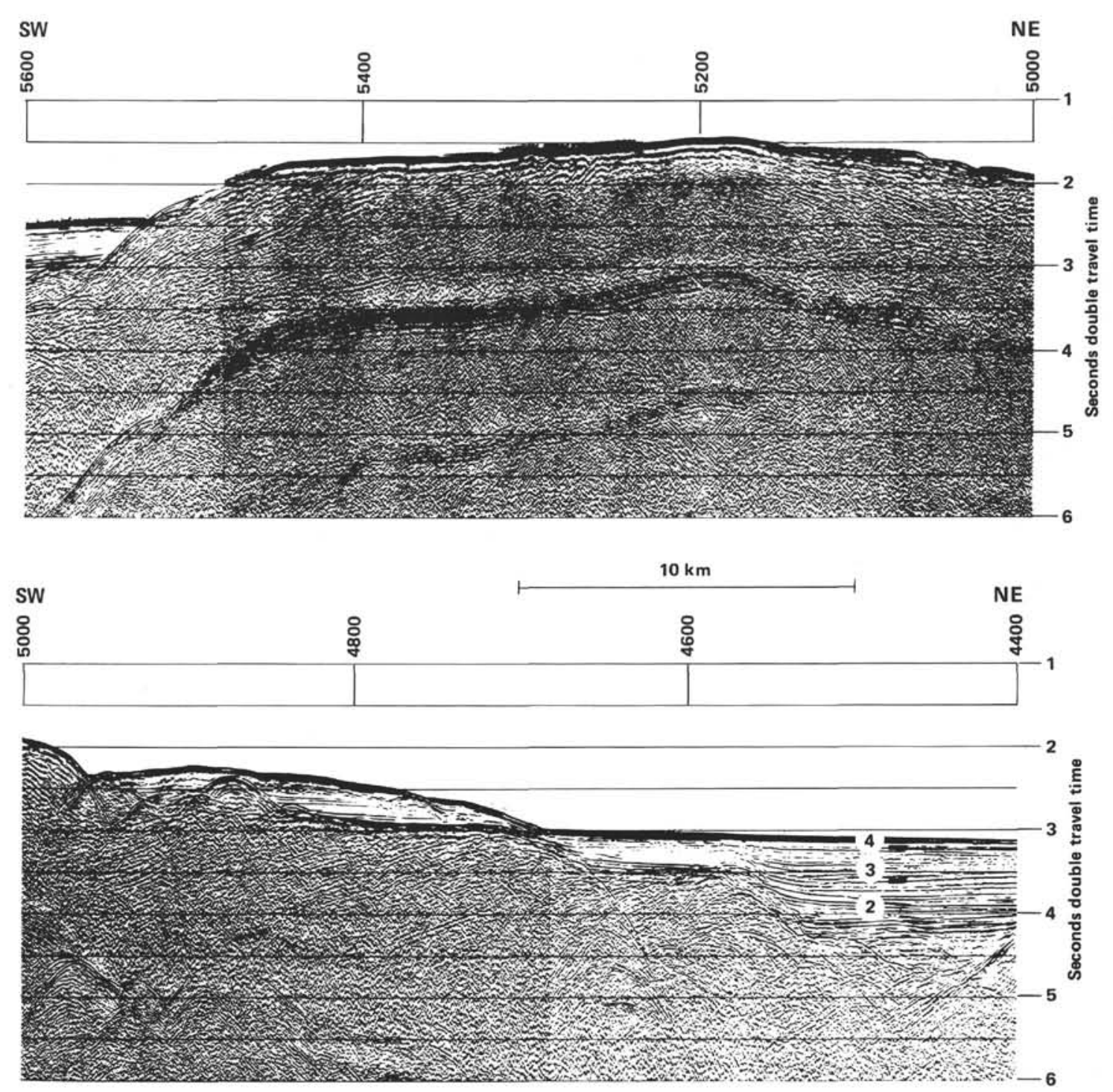

Figure 6. Processed seismic profile Wal 3 on the eastern Walvis Ridge. Location in Figure 2. Example of landward and oceanward dipping reflectors within the basement.

tinuities in the sedimentary sequence prevent the direct tying together of the sedimentary units of the Angola Basin and of the Walvis Ridge area. Correspondence between units of these two different regions has been established by DSDP holes at Site 530 in the Angola Basin and Sites 362 and 363 on the Walvis Ridge. The pattern of transgressive-regressive cycles established by Vail et al. (1977) does not give unique solutions in this area. The division of the sedimentary sequence by major unconformities is arbitrary in the sense that variations of the sedimentary regime permit each acoustic unit to be divided into subunits. Nevertheless, distinctive changes in the acoustic facies linked to the topography allow us to distinguish four areas: (1) geologic provinces 1 and 2 on the Walvis Ridge; (2) geologic provinces 3 and 4 on the Walvis Ridge; (3) Angola margin and basin; (4) Cape margin and basin.

\section{Acoustic Unit 1}

On the Walvis Ridge this first sequence rests on the dipping basement reflectors of structural provinces 1 and 2 and on the basaltic reflector of structural province 3. It fills in the depressions in the basement and especially the large north-south depression which is the boundary between provinces 1 and 2 and which contains more than 2 sdtt of sediments (Fig. 10). The base of Unit 1 consists mainly of chaotic reflectors that onlap the basement highs. There is an increase in the continuity of reflectors upward in the sequence, with the appearance of strong reflectors which are present only in provinces 1 and 2 . Acoustic Unit 1 wedges out in the middle part of province 3 .

In the Angola Basin, Unit 1 overlies the acoustic basement and wedges out westwards at the longitude of Site 530, where the reflector marking the top of Unit 1 onlaps the basement and appears to be discontinuous. Unit 1 may be present at Site 530, depending on the exact location of Site 530 with respect to the B.G.R. 41 seismic line (Figs. 3, 11). The thickness of this unit increases regularly to a maximum of $0.5 \mathrm{sdtt}$ at the foot of the continental margin immediately north of the ridge; its thickness decreases northwards. As on top of the 


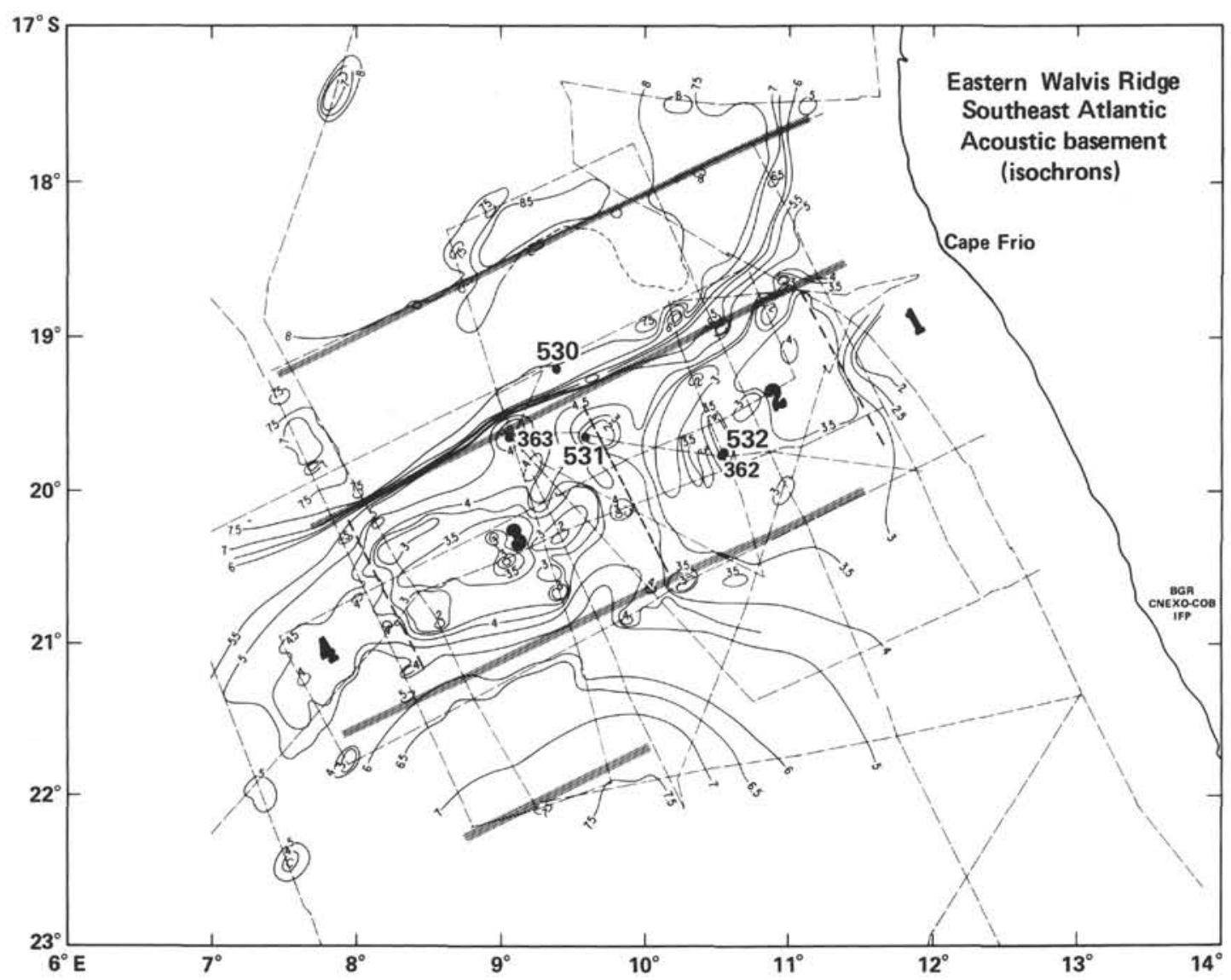

Figure 7. Basement map of the eastern Walvis Ridge area in seconds of double travel time (sdtt). Contour interval, $0.5 \mathrm{sdtt}$. Seismic control in dashed lines. The four main geologic provinces on the ridge are indicated by large numbers and their boundaries shown by heavy dashed lines. Hatchures correspond to inferred fracture zones.

ridge, this unit onlaps the basement topography and fills in depressions. Unit 1 is characterized by a series of reflectors which become hummocky close to the margin (Fig. 11), indicating a turbiditic origin from the Angolan continental margin.

\section{Acoustic Unit 2}

On the Walvis Ridge, acoustic Unit 2 is a well-layered sequence which decreases in thickness from $1.7 \mathrm{sdtt}$ at the eastern end of the profiles to $0.8 \mathrm{sdtt}$ near Site 362 and $0.4 \mathrm{sdtt}$ at the boundary between provinces 1 and 2 (Figs. 5, 6, and 10). This sequence is bounded by two major unconformities which correspond to major hiatuses associated with downlapping reflections. Unit 2 is characterized by a series of high-amplitude reflections with alternating downlapping and onlapping reflections which intersect. The character of the reflectors changes from uniformly flat and continuous in the west to wavy but continuous in the east. A major discontinuity exists in the middle of the acoustic unit and represents a significant hiatus. This discontinuity marks the base of several channels cut into the underlying sequence, which is characterized by onlapping reflectors and has a seismic character associated with hemipelagic and turbiditic sedimentation (Fig. 12). These channels trend along the Angola shelf from north to south; some of them lead down into the deep Angola Basin, and others lead into the basin located on the ridge.
In the Angola Basin, acoustic Unit 2 corresponds to acoustic Units 3 and 4 of the Site 530 chapter (this volume) and to acoustic Units 1 and 2 defined by Musgrove and Austin (this volume). Because the limits between Units 3 and 4 of the Site 530 chapter and Units 1 and 2 of Musgrove and Austin are not the same, but correspond in both cases to different minor low-angle discontinuities, it has been decided to consider these as minor units within a major sequence. Although these two discontinuities are separated by only 0.15 sdtt, they correspond to the transition between a lower subunit characterized by a series of low- to moderate-amplitude reflectors that form a variety of reflection configurations, and an upper subunit characterized by a series of uniformly continuous, high-amplitude, even to wavy parallel reflections (see Musgrove and Austin, this volume, for details). The top of Unit 2 is the major seismic discontinuity recognized as horizon A II (e.g., Emery et al., 1975) throughout the Angola Basin.

\section{Acoustic Unit 3}

Acoustic Unit 3 is a transparent layer (e.g., Figs. 3, 4, and 10) with faint and discontinuous subhorizontal reflectors and within which a minor discontinuity can be followed. The base of acoustic Unit 3 corresponds to a major discontinuity which can be traced throughout the Angola Basin and on the Walvis Ridge and has been named horizon A II by Emery et al. (1975). This acous- 


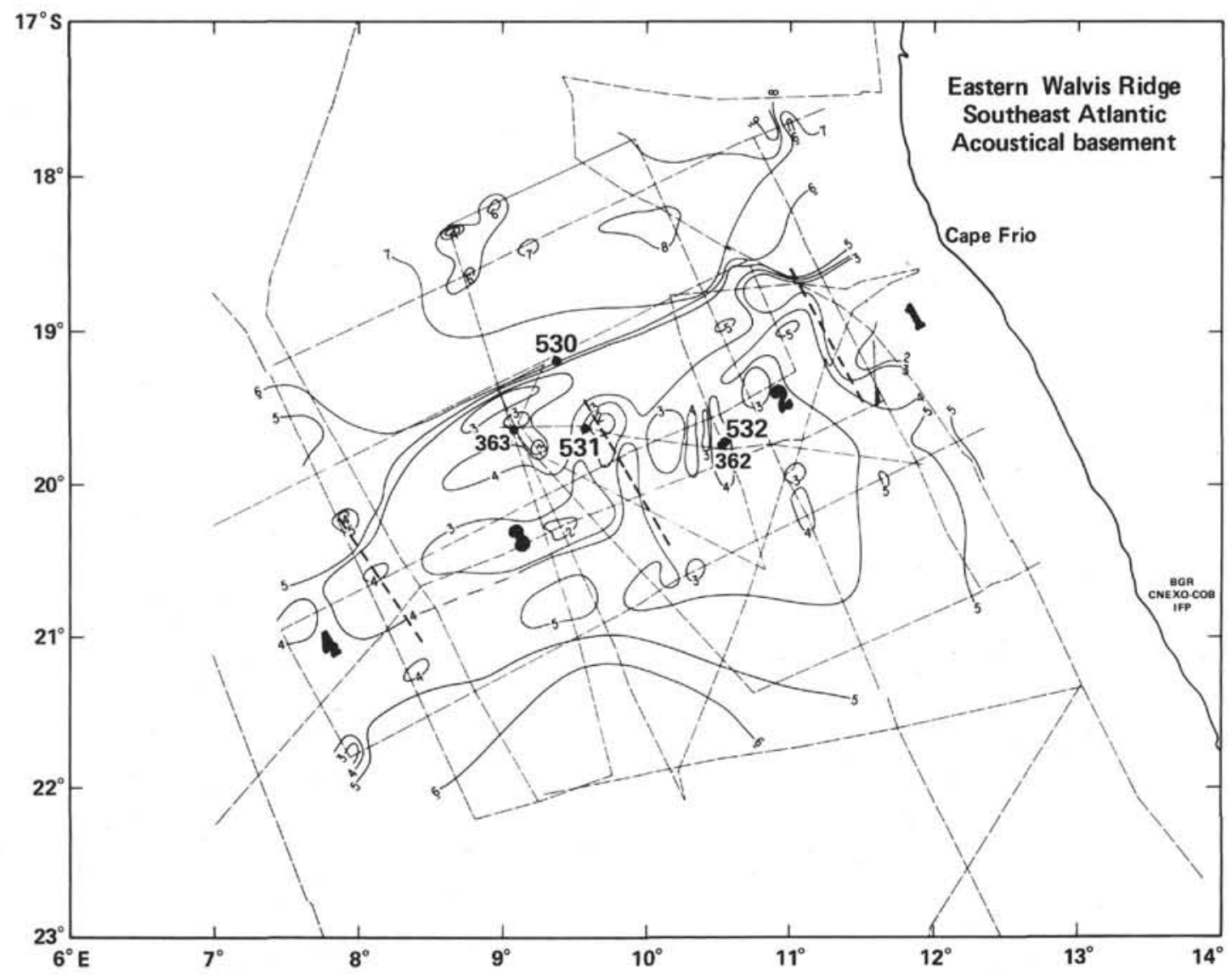

Figure 8. Basement map of the eastern Walvis Ridge in kilometers. Contour interval, $1 \mathrm{~km}$. Seismic control in dashed lines. The four main structural provinces on the ridge are indicated by large numbers and their boundaries shown by heavy dashed lines.

tic discontinuity clearly separates a lower stratified sequence from an upper transparent sequence; the contrast is enhanced on a constant gain seismic profile of the Glomar Challenger-type (Site 530 chapter, Fig. 66). Throughout the Angola Basin the lowermost acoustic subsequence of Unit 3 onlaps the existing topography which corresponds to the A II discontinuity. This is confirmed by the local (Musgrove and Austin, Fig. 17, this volume) and regional (Fig. 13) isopach maps of acoustic Unit 3 and by the local map of depth to the top of acoustic Unit 2 (Musgrove and Austin, Fig. 18, this volume). Acoustic Unit 3 locally thickens towards the north in the deep Angola Basin on the Musgrove and Austin isopach map for the vicinity of Site 530, but on the general isopach map (their Fig. 13), the thickness of acoustic Unit 3 decreases from the Angola shelf edge (0.9 sdtt) to the deep Angola Basin (0.2 sdtt at the level of Site 530). This suggests a primarily turbiditic input, which is also suggested by the medium- to high-energy seismic character of this unit.

On the Walvis Ridge the major input of sediment is from the shelf south of Cape Frio but north of the Walvis Ridge axis. The shape of isopachs is similar to those of a fan, with a maximum thickness greater than $0.9 \mathrm{sdtt}$ (Fig. 13). The faint reflector which divides acoustic Unit 3 in the Angola Basin could correspond to a strong reflector present on the Walvis Ridge, where it divides this unit into two subunits characterized by different levels of energy (Figs. 4 and 10). The lower subunit corresponds to two-thirds of the total thickness of acoustic Unit 3, with reflections of variable amplitude along hatched and often hummocky reflectors. The upper subunit produces an irregular reflection pattern characteristic of sedimentation in a high-energy environment. Deep sea fan features, such as channels, levees, and sigmoidal bodies, are commonly observed in this upper subunit on the easternmost Walvis Ridge (Figs. 10, 12, 14 , and 15). Large-scale tectonic movements apparently occurred at the time corresponding to the interface between acoustic Units 3 and 4; these resulted in a smoothed irregular topography and small vertical offset normal faults (Figs. 14, 16).

\section{Acoustic Unit 4}

In the Angola Basin, acoustic Unit 4 is characterized by discontinuous subparallel or hummocky reflections (Fig. 3) with lateral variations both perpendicular (Musgrove and Austin, this volume) and parallel to the Walvis Ridge. Consequently, acoustic Unit 4 is partly a series of slumps and flows coming from the top of the northern Walvis Ridge. The local Miocene to Recent isopach map of Musgrove and Austin (see their Fig. 23, this volume) indicates two sources of sediments, one 


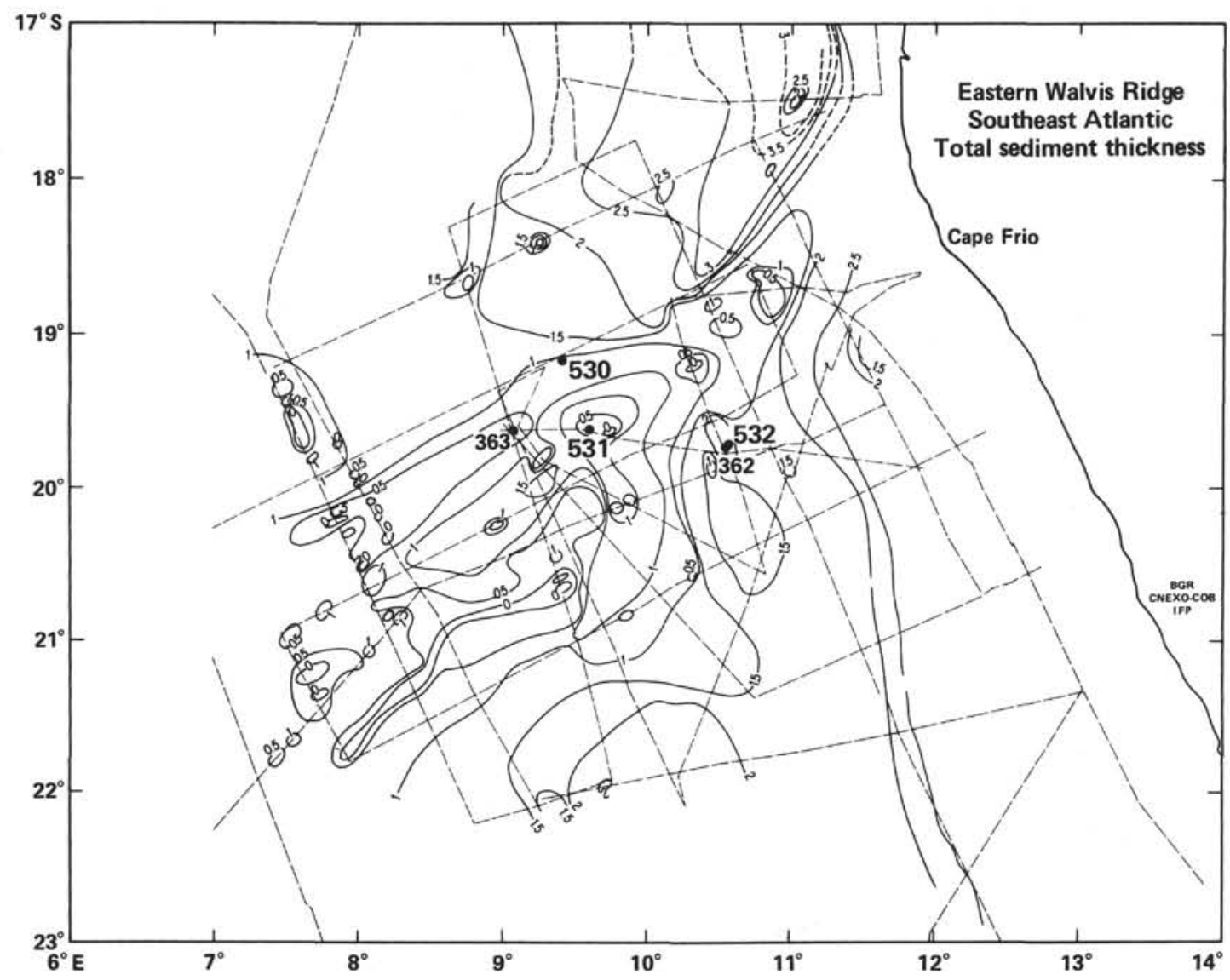

Figure 9. Time isopach map of the sedimentary cover. Contour interval, $0.5 \mathrm{sdtt}$. Seismic control in dashed lines.

W
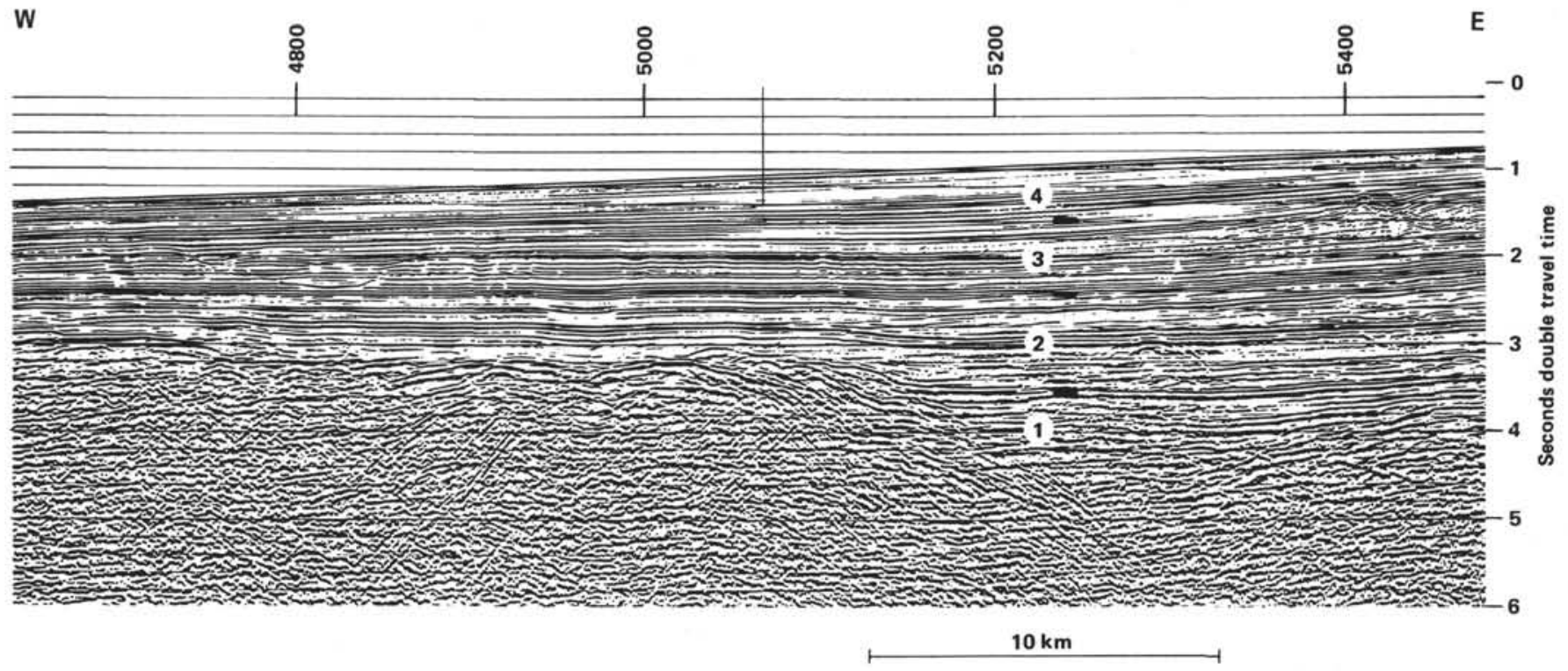

Figure 10. Processed seismic profile BGR-36 on the eastern Walvis Ridge. Location in Figure 2. The main acoustic units are identified as follows: Unit 1, older than Cenomanian; Unit 2, Cenomanian to early Oligocene; Unit 3, early Oligocene to early late Miocene; Unit 4, early late Miocene to present.

from the southeast and another from the northeast. This is also suggested by the regional isopach map of Figure 17, where input from both the ridge and the Angola margin is suggested. These interpretations are confirmed by Stow (this volume), who describes the pres- ence of a deep sea fan at Site $\mathbf{5 3 0}$ ("brown fan") which was active during the whole time of deposition of acoustic Unit 4.

On the Walvis Ridge, acoustic Unit 4 corresponds to the infilling of the topography created at the end of de- 
SW

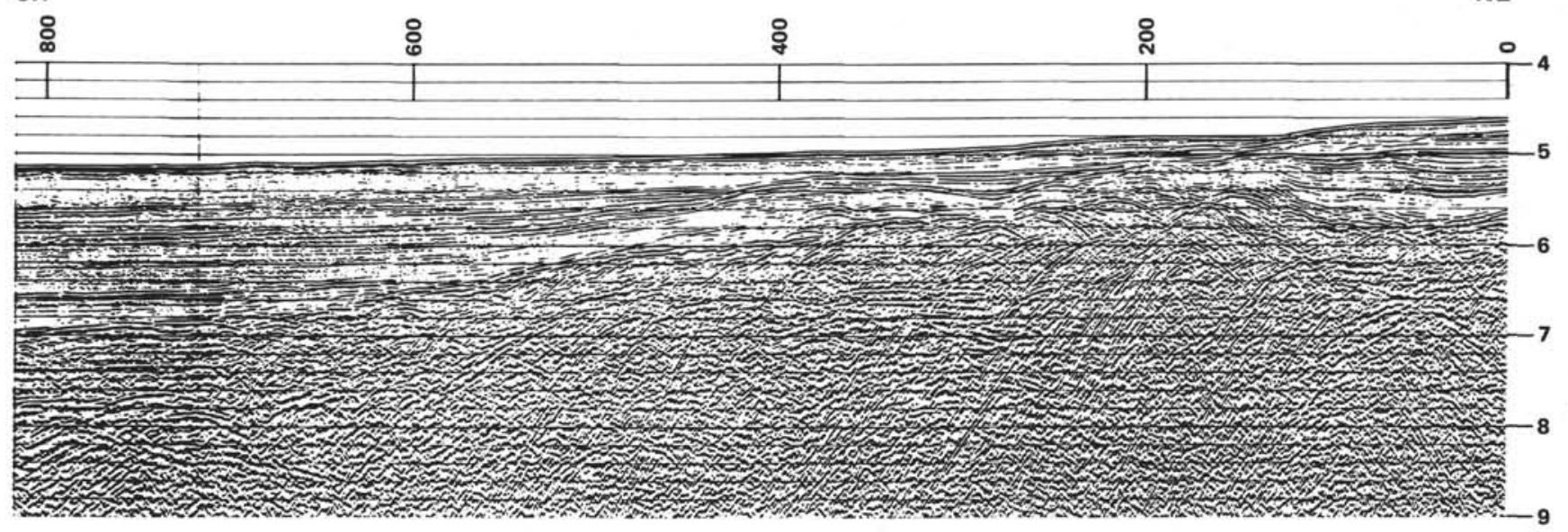

NE
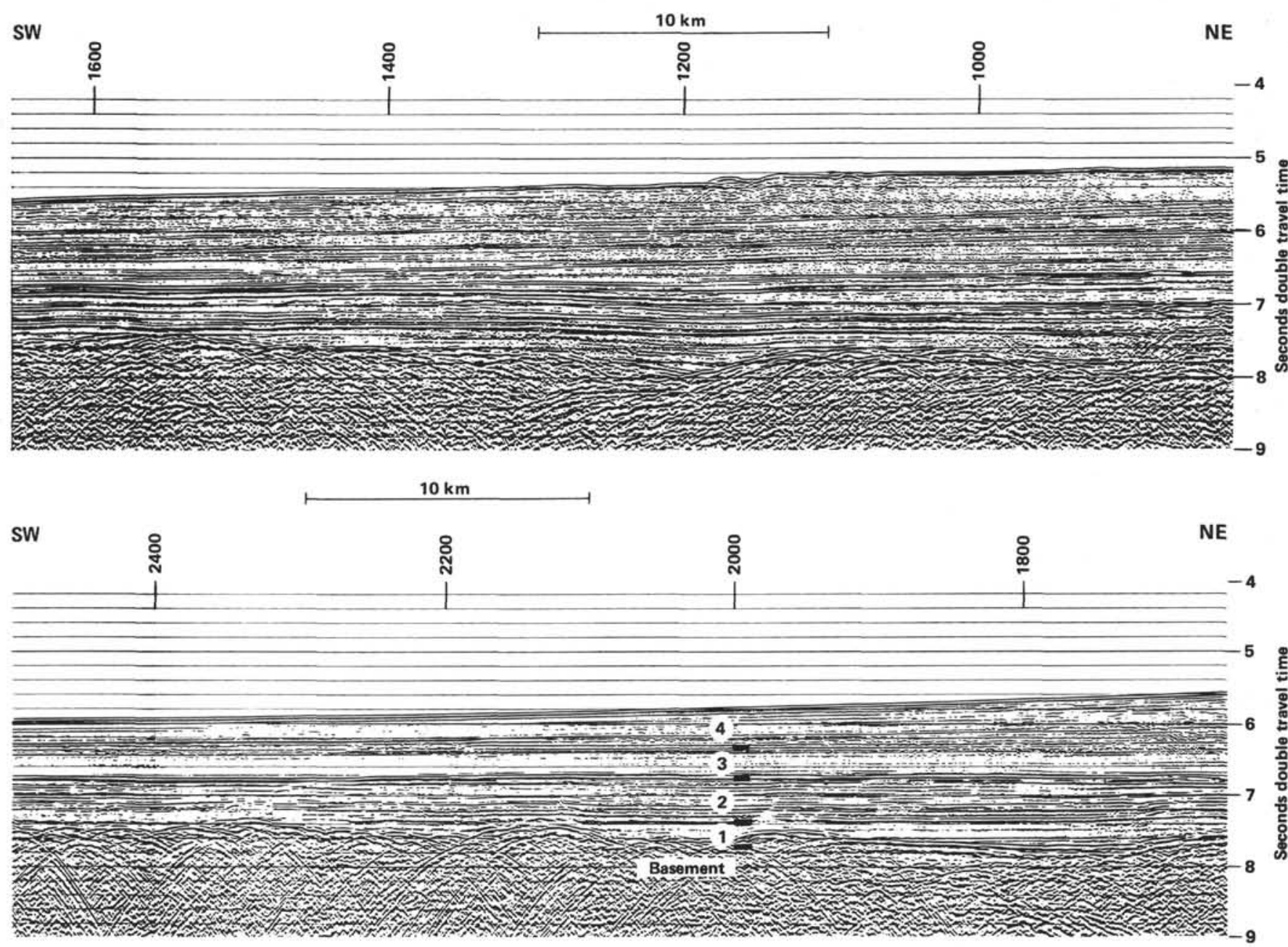

Figure 11. Processed seismic profile BGR-41 in the Angola Basin. Location in Figure 2. The main acoustic units are identified: Unit 1, older than

Cenomanian; Unit 2, Cenomanian to early Oligocene; Unit 3, early Oligocene to early late Miocene; Unit 4, early late Miocene to present.

position of acoustic Unit 3 (Figs. 5 and 14). This is reflected on the late Miocene to Recent isopach map (Fig. 17) by an irregular pattern. Regionally, the seismic character of acoustic Unit 4 changes from a well-stratified sequence to a younger, slightly less stratified to wavy sequence, probably reflecting the effect of bottom currents on the top of the eastern Walvis Ridge. The isopach map (Fig. 17) indicates the origin of the sediments to be partly from the continental shelf and slope of the South African margin.

\section{Correlation of the Acoustic Stratigraphy with Leg $\mathbf{4 0}$ and 75 Results}

Site 530 is located near BGR profile 41 (Figs. 3 and 11) while Sites 363,531 , and $532 / 362$ are all located near BGR profile 36 (Fig. 18). 


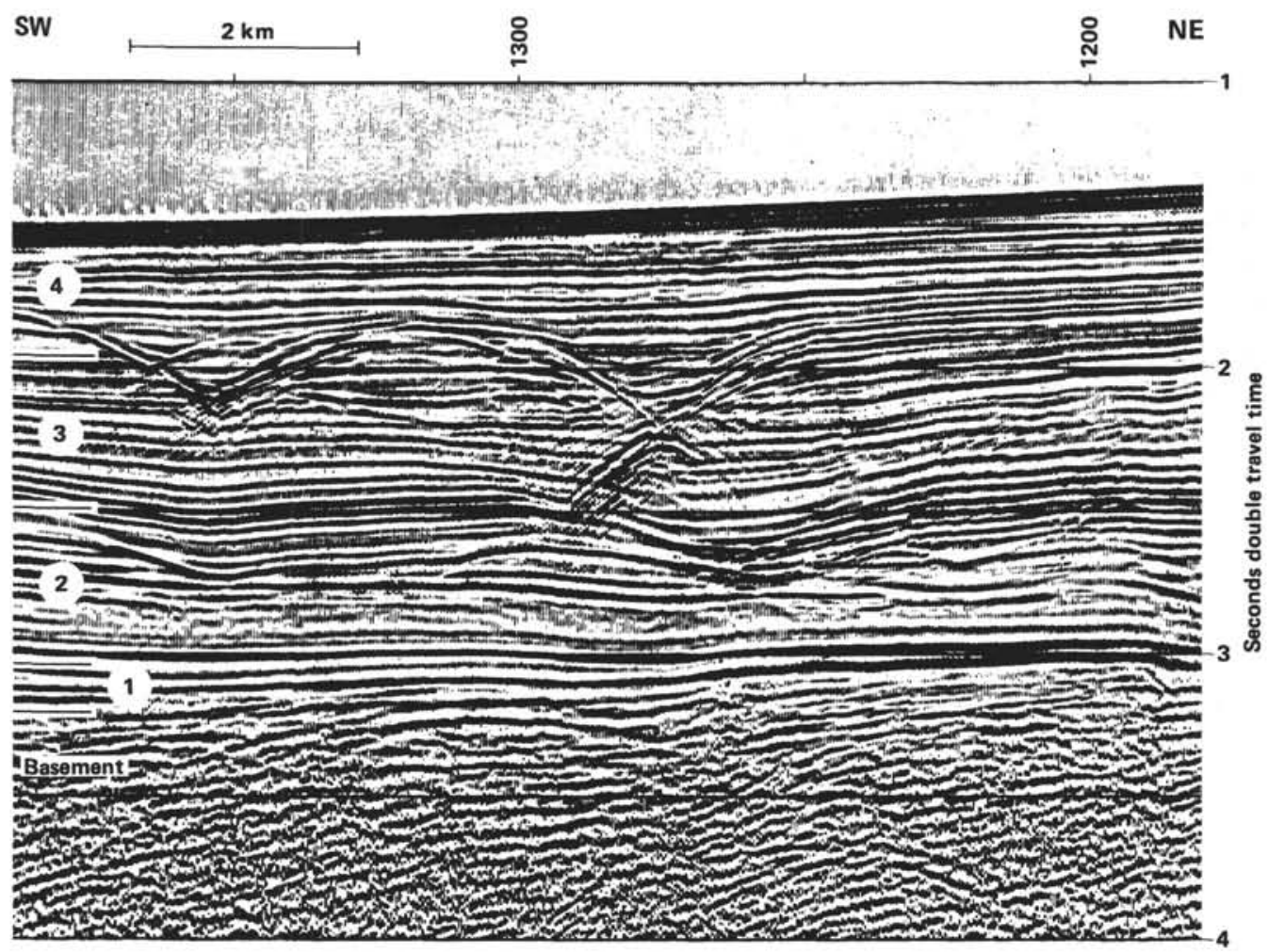

Figure 12. Detail of processed seismic profile Wal 3 on the eastern Walvis Ridge showing channels sculpturing acoustic Units 2 and 3. Location in Figure 2. The main acoustic units are identified as follows: Unit 1, older than Cenomanian; Unit 2, Cenomanian to early Oligocene; Unit 3, early Oligocene to early late Miocene; Unit 4, early late Miocene to present.

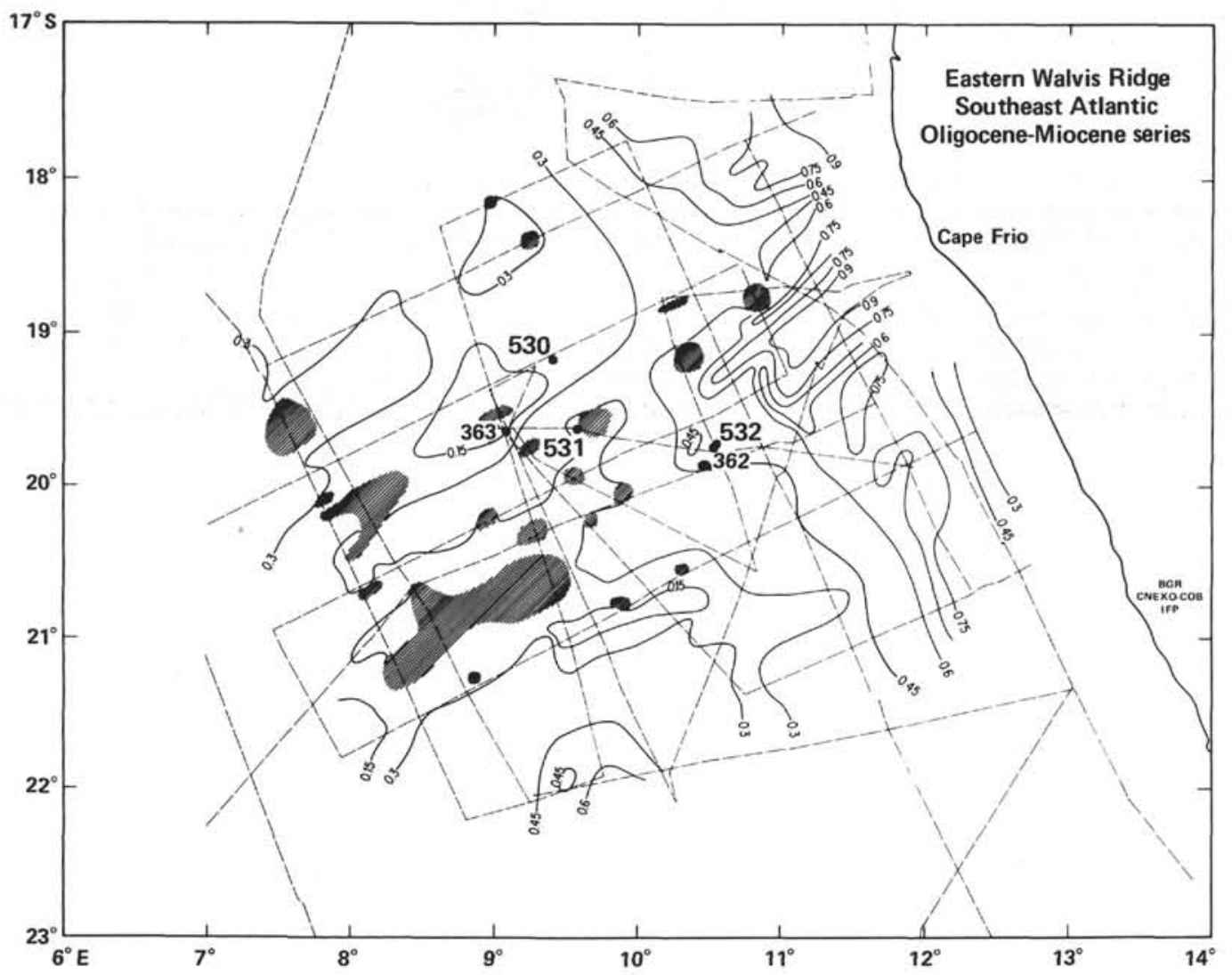

Figure 13. Isopach map of acoustic Unit 3 (early Oligocene to early late Miocene) in sdtt. Contour interval, 0.15 sdtt. Seismic control in dashed lines. Sedimentary hiatuses hatchured. 

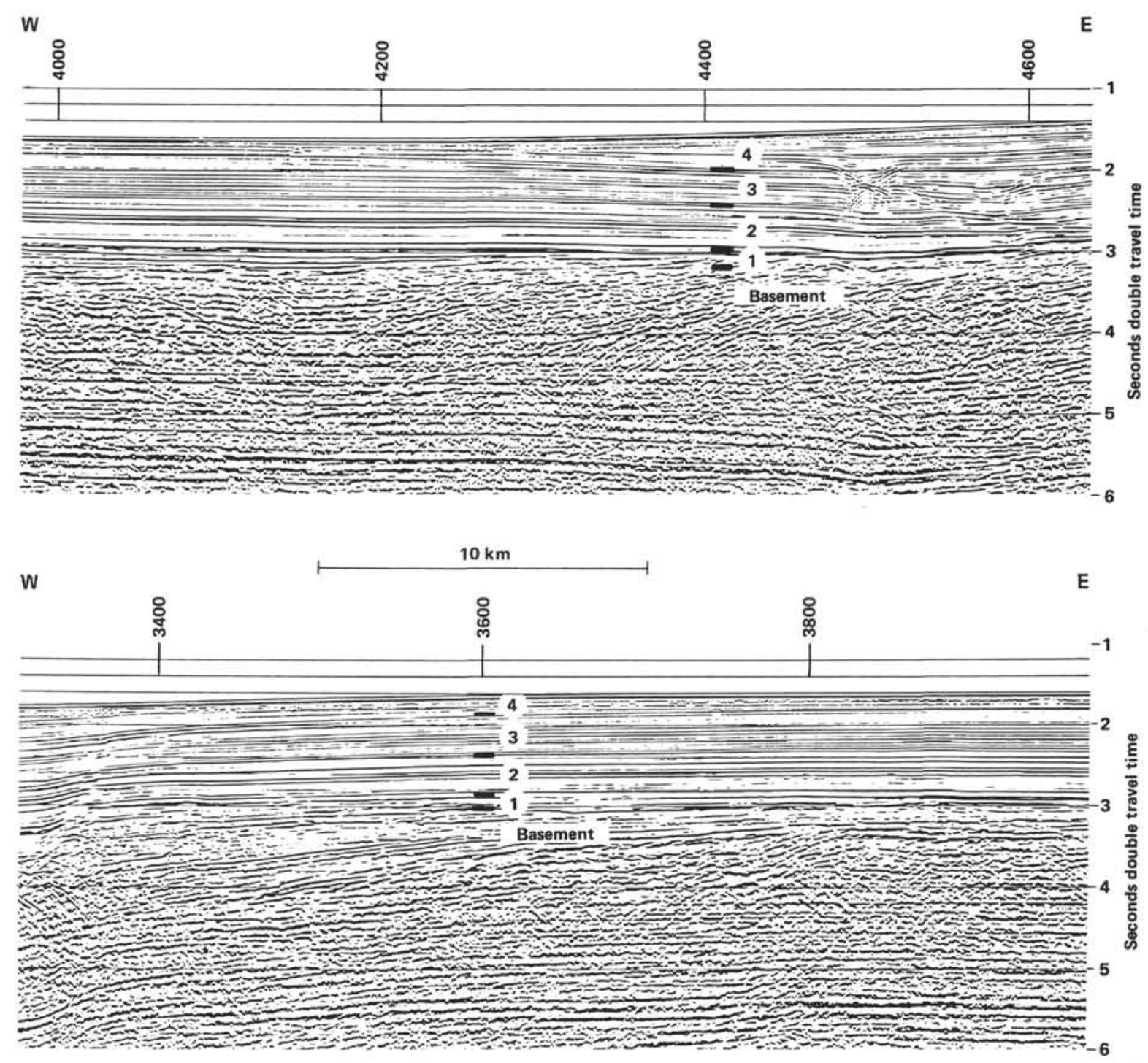

Figure 14. Processed seismic profile BGR-36 on the eastern Walvis Ridge showing channels in acoustic Unit 3. Location in Figure 2. The main acoustic units are identified as follows: Unit 1, older than Cenomanian; Unit 2, Cenomanian to early Oligocene; Unit 3, early Oligocene to early late Miocene; Unit 4, early late Miocene to present.

\section{Site 530 (Figs. 19, 20)}

Site 530 is located in the deep Angola Basin about $100 \mathrm{~km}$ west of the Angola continental ocean boundary (Hay, Sibuet et al., 1982). Acoustic Unit 1 is absent or represented by 50 to $100 \mathrm{~m}$ of basal sediments of probable Cenomanian to Albian age (Steinmetz et al., this volume). Acoustic Unit 2 is complete; it corresponds to acoustic Units 3 and 4 defined in the Site 530 chapter and to Units 1 and 2 of Musgrove and Austin (this volume). Because the base of acoustic Unit 2 is close to the basement in the vicinity of Site 530 , the boundary between acoustic Units 1 and 2 is not firmly established by drilling but may correspond to a hiatus near the Cenomanian/Turonian boundary. Acoustic Unit 2 corresponds to lithologic Units 8 (red and green claystone, and marlstone with interbedded black shales), 7 (variegated red, green, and purple claystone, siltstone, and sandstone), and 6 (volcanogenic sandstone), which are of early Campanian to late Albian age (790-1003 m,
77.5-102.5 m.y.), and then to lithologic Units 5 (mudstone, marlstone, clastic limestone, and siliclastic sandstone), and 4 (multicolored mudstone, marlstone, chalk, and clastic limestone), which are of Eocene to early Campanian age (467-790 m, 37-77.5 m.y.) (see Site 530 chapter, this volume). The boundary between the transparent and layered sequences corresponds to the boundary between lithologic Units 5 and 6, which is associated with a possible lower Campanian hiatus or at least with a change in sedimentation rate (Site 530 chapter, this volume). This boundary also corresponds to Anomaly 34, which marks a change in the South Atlantic kinematic motions (e.g., Sibuet and Mascle, 1978). Musgrove and Austin (this volume) have placed this boundary within the Campanian at $704.5 \mathrm{~m}$ sub-bottom water depth, corresponding to the boundary between lithologic Subunits $5 \mathrm{~b}$ and $5 \mathrm{c}$.

The boundary between acoustic Units 2 and 3 (Reflector A II) is identified as the middle Eocene-middle Oligocene condensed section or hiatus ( $467 \mathrm{~m}$ ). A major 
SW

$10 \mathrm{~km}$

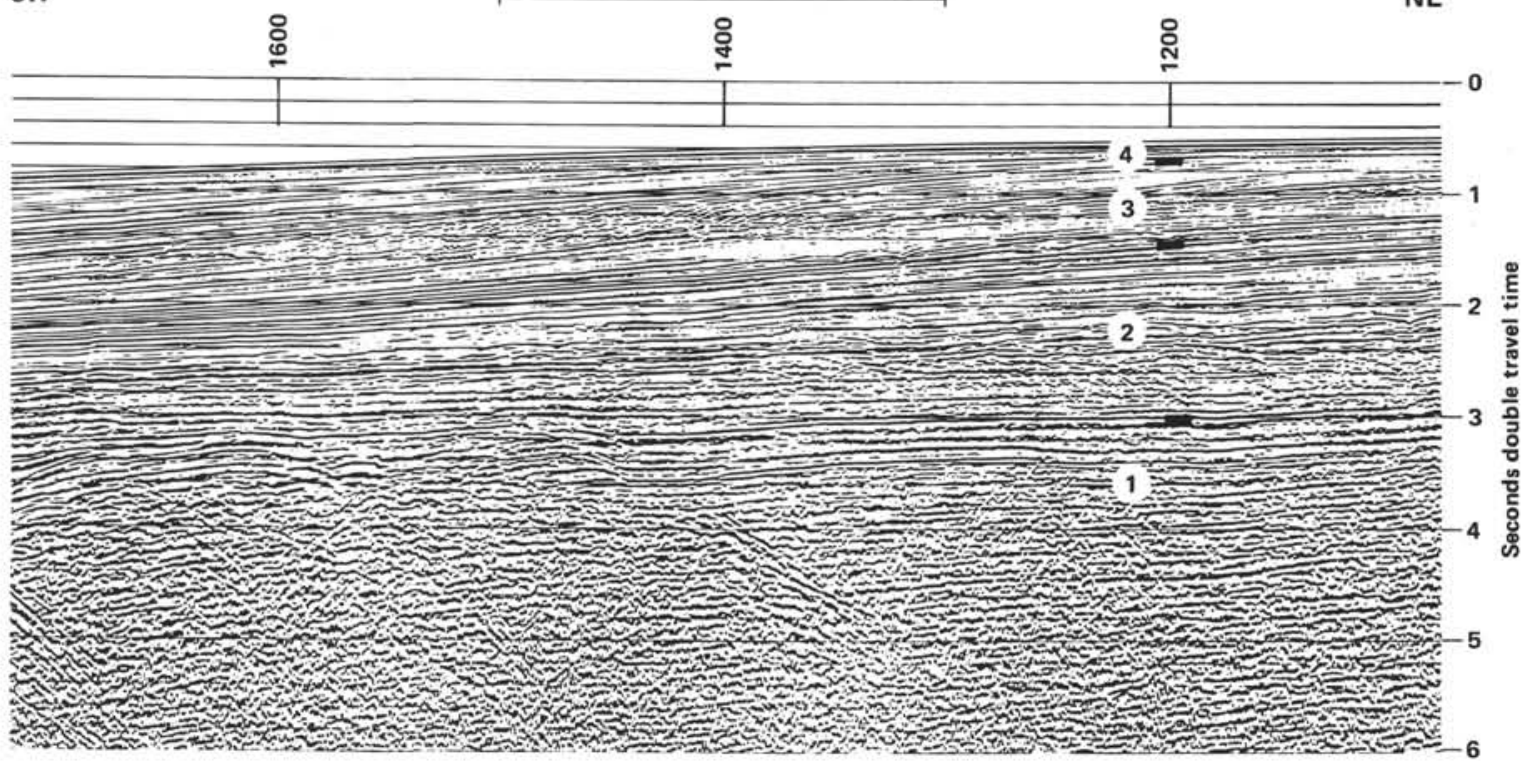

Figure 15. Sigmoidal bodies in acoustic Unit 3. Processed seismic profile BGR-37 on the eastern Walvis Ridge. Location in Figure 2. The main acoustic units are identified as follows: Unit 1, older than Cenomanian; Unit 2, Cenomanian to early Oligocene; Unit 3, early Oligocene to early late Miocene; Unit 4, early late Miocene to present.

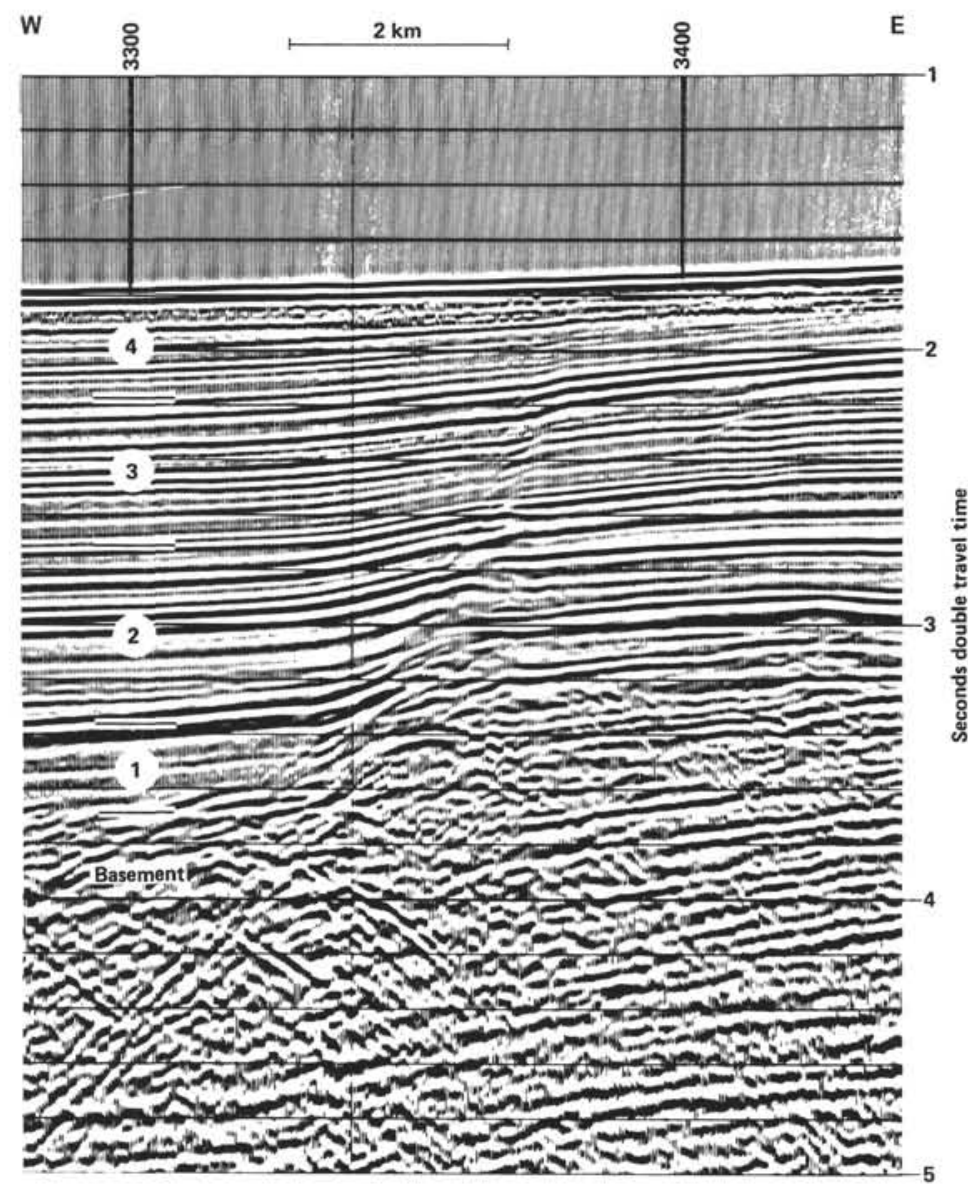

Figure 16. Normal faulting ending at the end of deposition of acoustic Unit 3. Processed profile BGR-36 on the eastern Walvis Ridge. Location in Figure 2. The main acoustic units are identified as follows: Unit 1, older than Cenomanian; Unit 2, Cenomanian to early Oligocene; Unit 3, early Oligocene to early late Miocene; Unit 4, early late Miocene to present. 


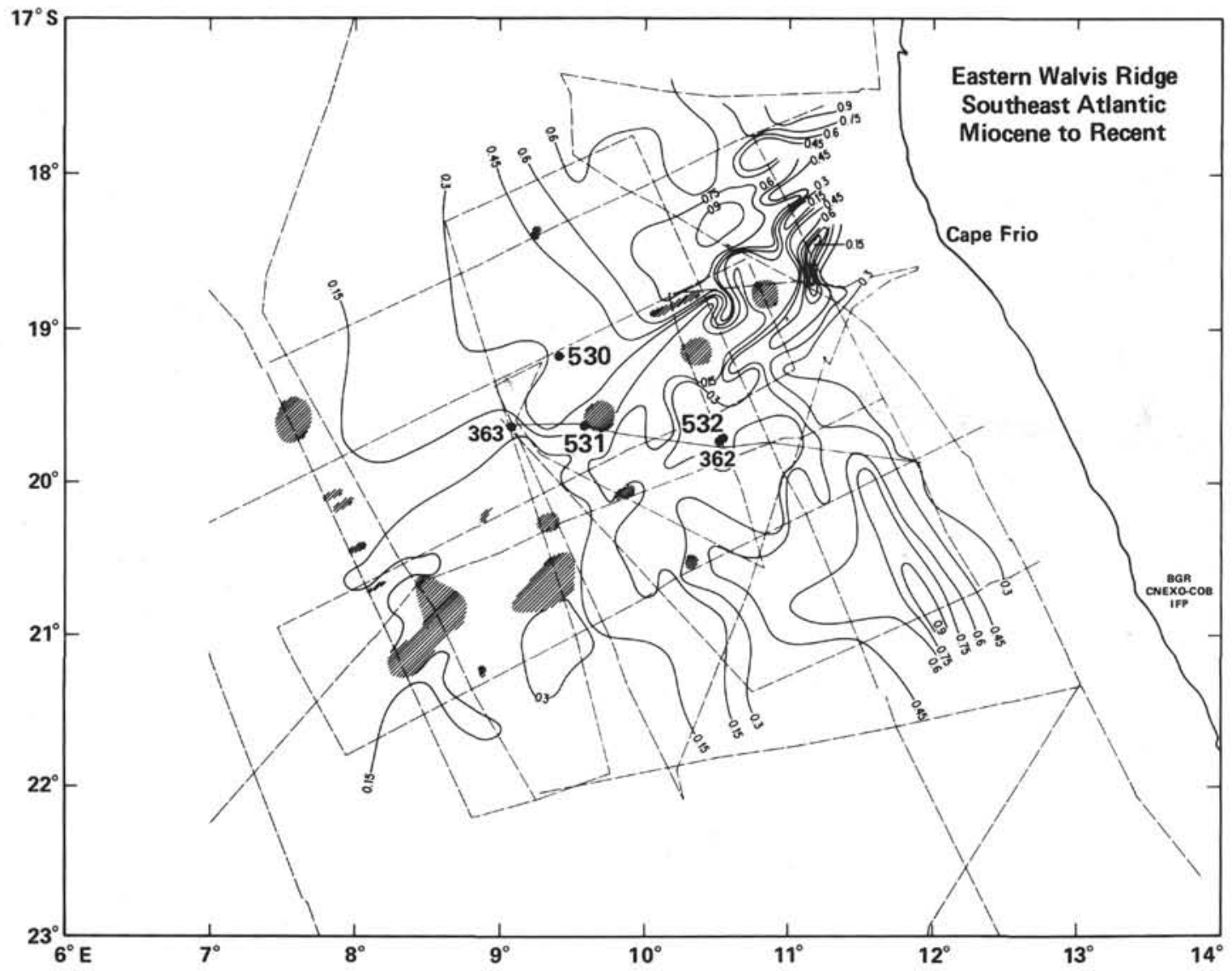

Figure 17. Isopach map of sediments deposited from late Miocene to present (acoustic Unit 4). Contour interval, 0.15 sdtt. Seismic control in dashed lines. Sedimentary hiatuses hatchured.

change in the physical properties occurs at this level (Boyce, this volume). Acoustic Unit 3 corresponds to the lithologic Unit 3, a red and green mud sequence of late Oligocene to late Miocene age (277-467 m, 10-37 m.y.). The acoustic discontinuity at the top of Unit 3 represents a short early late Miocene hiatus corresponding to the $\mathrm{CN} 6$ and 7 calcareous nannofossil zones. Acoustic Unit 4 corresponds to lithologic Units 2 (nannofossil clay, marl, and ooze, and debris-flow deposits) and 1 (nannofossil and diatom smarl, marl and ooze, diatom ooze and debris-flow deposits) of late Miocene to Recent age (0-277 m, 0-10 m.y.).

\section{Site 531 (Figs. 18, 21)}

Only a rock fragment, consisting of sand-size fragments of volcanic rocks, red coralline algae, and mollusks, has been recovered on the top of a guyot-like feature located on the Walvis Ridge. From subsidence considerations, this reef-like cap is probably of Cretaceous age and probably formed in less than $250 \mathrm{~m}$ of water as indicated by the restricted paleowater depth of the calcareous algae recovered at this site (Site 531 chapter, this volume).

Sites 362 and 532 (Figs. 22, 23)

Site 362 (Leg 42) was drilled by rotary methods in the central basin located on top of the Walvis Ridge. Site 532 was located in immediate proximity to Site 362 , and was sampled by hydraulic piston coring during Leg 75 . Using velocities measured at Site 362 (Sites 362, 363, Bolli, Ryan et al., 1978), acoustic Unit 4 is $335 \mathrm{~m}$ thick and corresponds to lithologic Units 1 (marly nanno ooze and nanno ooze) and part of lithologic unit $2 \mathrm{a}$ (marly chalk). The base of this unit has been defined as reflector green on the Walda profile 11 (Goslin et al., 1974) by Bolli, Ryan et al. (1978) and is dated early late Miocene. No clear hiatus has been identified at Site 362 and the sedimentary sequence appears to be rather continuous. Tracing the boundary between acoustic Units 4 and 3 laterally (Fig. 18, shot point 2500 on BGR-36 line) shows that at least part of the late Miocene strata are eliminated, suggesting that there were some early late Miocene tectonic movements.

The base of acoustic Unit 3 is at 1.0 sdtt on the seismic profile in Fig. 22, which corresponds to a depth of $920 \mathrm{~m}$ using the velocities measured in Holes 362 and $362 \mathrm{~A}$. Consequently the base of acoustic Unit 3 corresponds to the base of lithologic Unit 3, a marly nannofossil chalk with intercalations of "Braarudosphaera" chalk. The Braarudosphaera blooms are characterized throughout the Walvis area by strong acoustic reflectors that are particularly apparent on constant gain seismic profiles (Site 362-363 chapter, Bolli, Ryan et al., 1978, and Site 532 chapter, this volume). The age of the base of acoustic Unit 3 is early Oligocene, but the position of this boundary cannot be located with a precision better 
than a few tens of meters in the lithologic column. Acoustic Unit 3 therefore corresponds to lithologic Unit 3 (marly nannochalk with Braarudosphaera chalk intercalations), lithologic Subunits $2 c, 2 b$, and part of $2 a$ (foraminifer-nannofossil chalk, marly nannochalk) (Fig. 23).

Only part of acoustic Unit 2 is represented at Site 362 by lithologic Unit 4 (marly nannofossil limestone). The base of acoustic Unit 4 may correspond to the yellow (2) reflector defined by Bolli, Ryan et al. (1978) at $1.6 \mathrm{sdtt}$ (Fig. 21). If this identification is valid, then the Cenomanian discontinuity identified in the Angola Basin would also correspond to this reflector. Assuming a $3.0 \mathrm{~km} / \mathrm{s}$ velocity for the acoustic layer between 1.3 and $1.6 \mathrm{sdtt}$, this reflector would be at $1,800 \mathrm{~m}$ which is about two times deeper than the base of the Oligocene $(920 \mathrm{~m})$. Since the sedimentary sequence at Site 362 seems to be complete, this estimate for the depth of the Cenomanian discontinuity compares favorably with that projected from the mean relative sedimentation rate for DSDP holes, which predicts that it should be deeper than the base of the Oligocene by a factor of two.

\section{Site 363 (Figs. 24, 25)}

Site 363 was drilled on the top of the northern flank of the eastern Walvis Ridge (Fig. 1), where alkali basalts belonging to the acoustic basement have been dredged (Hékinian, 1972).

Acoustic Unit 4 is not detectable on the seismic profiles (Fig. 24) and is represented by only $1.5 \mathrm{~m}$ of latemiddle Miocene sediments recovered at the top of Hole 363. Two major acoustic reflectors can be identified on the processed seismic profile BGR-36 (Figs. 18, 24) at 0.12 and $0.18 \mathrm{sdtt}$ near Site 363 , but these irregular reflectors define acoustic layers of variable thicknesses over the top of the northern ridge. Because of the distance between the position of Hole 363 and the BGR-36 profile, direct correlation between the seismic and lithostratigraphic data is uncertain, but two groups of closed identified hiatuses which limit major lithologic units allow us to propose a reasonable correlation with the previously defined acoustic units.

The base of acoustic Unit 3 is probably the late Eocene-early Oligocene hiatus (Fig. 25) at $189 \mathrm{~m}$, and the acoustic unit corresponds to lithologic Subunits 1b (Braarudosphaera ooze and foraminifer-nannofossil chalk) and 1a (foraminifer-nannofossil ooze) (Fig. 25).

The base of acoustic Unit 2 is probably the late Cenomanian-Turonian hiatus at $435 \mathrm{~m}$, so that the acoustic unit corresponds to lithologic Subunits 2a (foraminifer-nannofossil chalk, marly nannofossil chalk), 1d and 1c (foraminifer-nannofossil chalk) (Fig. 25).

Late Aptian-Albian limestones and Cenomanian marly chalk would belong to the upper part of acoustic Unit 1 .

\section{Sedimentary Evolution}

Multichannel seismic reflection data allow us to extend knowledge of the sedimentary and geologic evolution of the eastern Walvis Ridge and the adjacent Angola Basin beyond the area of the drill sites. Integrating DSDP data, four major stratigraphic units have been identified over the oceanic basalt basement in the Angola Basin and in the western part of the eastern Walvis Ridge (geologic provinces 3 and 4). On the easternmost Walvis Ridge, deep reflectors within the basement dip oceanwards in structural provinces 1 and 2 and sporadically in structural provinces 3 and 4 . These dipping reflectors may represent successive fluid basalt flows with possible interbeds of sediments and tuffs emplaced on pre-existing topography (e.g., Hinz, 1981; Mutter et al., 1982; Roberts, Schnitker et al., 1982). In an extensional environment some of the dipping reflectors may represent prerift sedimentary reflectors within tilted fault blocks, as will be discussed further.

Albian and possible late Aptian sediments of acoustic Unit 1 were deposited in the southeastern oceanic part of the Angola Basin and do not exist west of the longitude of Site 530. The thickness of these sediments decreases westward with decreasing age of the oceanic crust. The hummocky character of these infilling sediments suggests that they were deposited by turbidity currents derived from the Angola continental margin. On the ridge, the north-south basin at the boundary between structural provinces 1 and 2 has been partly filled with lower Cretaceous detrital sediments. More distal turbidites occur in province 2 west of the north-south basin. Late Aptian-Albian limestones with terrigenous components occur on the top of the northern ridge, which was close to sea level at that time.

Late Cenomanian to early Oligocene sediments are mostly marly limestones in the central basin of Walvis Ridge and marly chalk to chalk on the northern ridge. A major pulse of terrigenous sedimentation ended in the late Campanian. This pulse of terrigenous influx may reflect a peak of current activity which eroded sediments off the Walvis Ridge and deposited them in the adjacent basins (Bolli, Ryan et al., 1978). In the Angola Basin, fan deposits occurred throughout this period. These fan deposits range from volcanogenic turbidites in the Campanian to siliciclastic turbidites in the Late Cretaceous and earliest Tertiary and to thick chalk turbidites from Paleocene to late Eocene. Late Cretaceous volcanic activity on the Walvis Ridge is documented by volcanic wedges interbedded with the sediments (Figure 26).

Early Oligocene to late Miocene red and green mud characterizes a quieter period in the Angola Basin, with a small influx of turbiditic sediment probably derived from the Angola continental margin. On the Walvis Ridge, the marly ooze to marly chalk of equivalent age shows extensive bioturbation. Cyclic sediments with pulses of terrigenous material alternate with more purely biogenous sediments; submarine fan development is indicated by channels, levees, and sigmoidal bodies (Figs. 12, 14, and 15), reflecting terrigenous influx from the northeast.

Upper Miocene to Recent sediments on Walvis Ridge are calcareous and siliceous, biogenic, open-marine pelagic deposits with variable amounts of terrigenous clay and a high organic carbon content reflecting the development of the Benguela upwelling system which began in the late Miocene (Siesser, 1980; Sites 530 and 532 
W
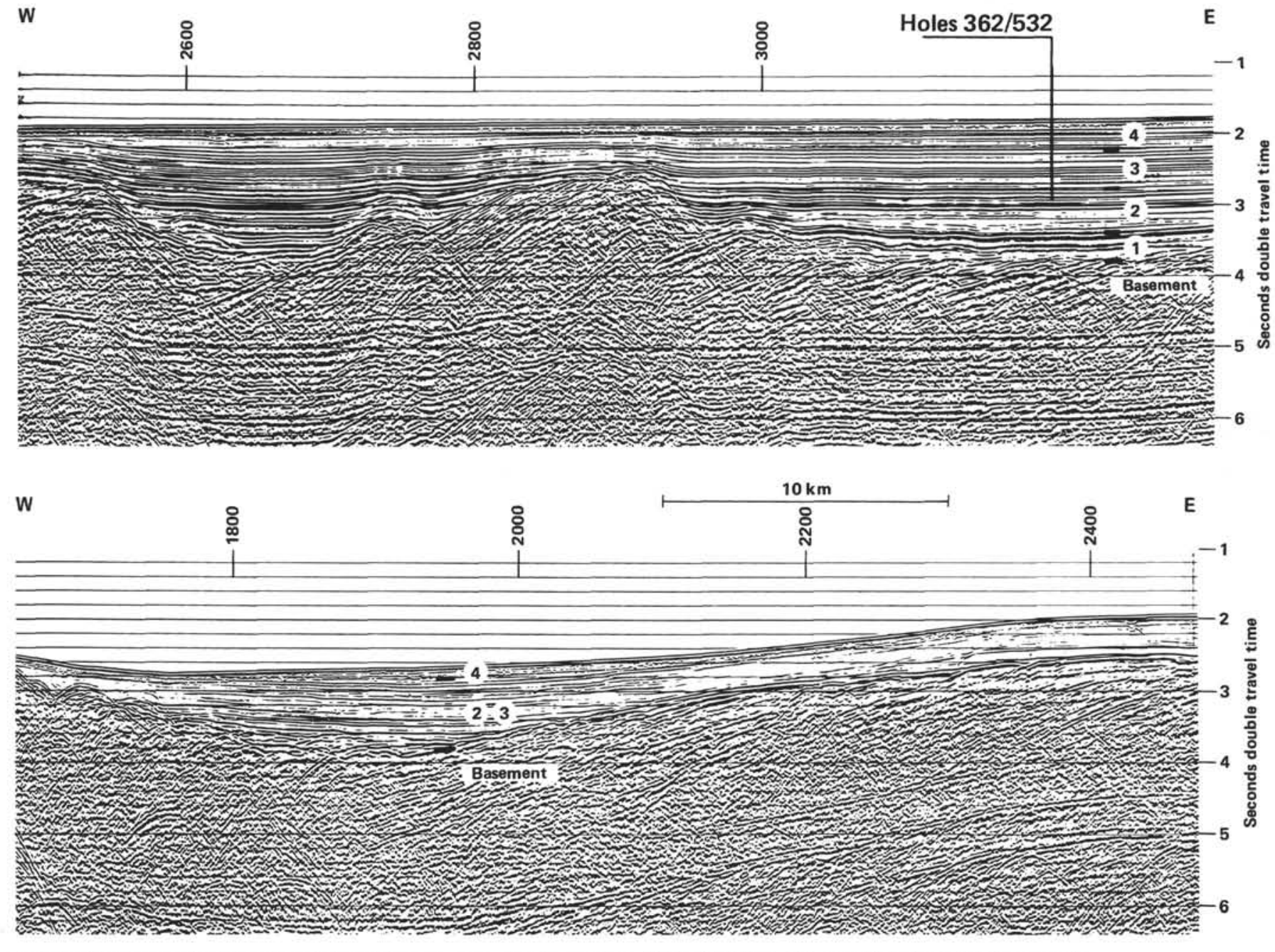

Figure 18. Processed seismic profile BGR-36 on or near which are located Sites 362/532, 531, and 363. Location in Figure 2.

chapters, this volume). These sediments are the main source for the turbidites and debris-flow deposits of equivalent age emplaced in the Angola Basin at the foot of the northern flank of the ridge (see Stow, this volume). Part of the upper Miocene to Recent sediments deposited in the Angola Basin were derived from the Angola continental margin as shown by the isopach map (Fig. 17); these sediments smoothed the topography which had been acquired during the late Miocene when large-scale tectonic movements deformed both the Walvis Ridge (Fig. 18) and, to a lesser extent, the Angola Basin.

\section{STRUCTURAL EVOLUTION OF THE WALVIS RIDGE}

Goslin and Sibuet (1975) have shown that the structural pattern and evolution of the Walvis Ridge and adjacent basins could be documented largely by gravity and magnetic data. Consequently, a magnetic anomaly map and a new free-air gravity anomaly map have been compiled.

\section{Magnetic Data}

Magnetics were extracted from the BNDO (Bureau National des Données Océaniques, Brest) data bank, which contains data from Woods Hole Oceanographic Institution (R/V Atlantis II and Chain), Lamont-Doherty Geological Observatory (R/V Vema and Conrad), the Deep Sea Drilling Project at Scripps Institution of Oceanography (D/V Glomar Challenger), and the Centre Océanologique de Bretagne (R/V Jean Charcot). These have been combined with more recent magnetic data obtained by the Bundesanstalt für Geowissenschaften und Rohstoffe (R/V Explora) and the Institut Français du Pétrole (R/V Résolution). Magnetic anomalies have been computed using the 1975 International Geomagnetic Reference Field (IGRF). Discrepancies of as much as $100 \mathrm{nT}$ existed at some profile intersections. These discrepancies are mainly the results of the imperfect definition of the secular variation and of the fact that diurnal variations and magnetic storms were not removed. Because the BGR survey is a homogenous regional survey, all previous data have been slightly adjusted to it. A $200 \mathrm{nT}$ contour interval was used for the magnetic anomaly map (Fig. 27).

High-amplitude short-wavelength magnetic anomalies characterize the main part of Walvis Ridge and reflect the volcanic nature of the acoustic basement. Volcanics may also occur in geologic province 1 , where the amplitudes are less. The northern limit of the ridge 
W
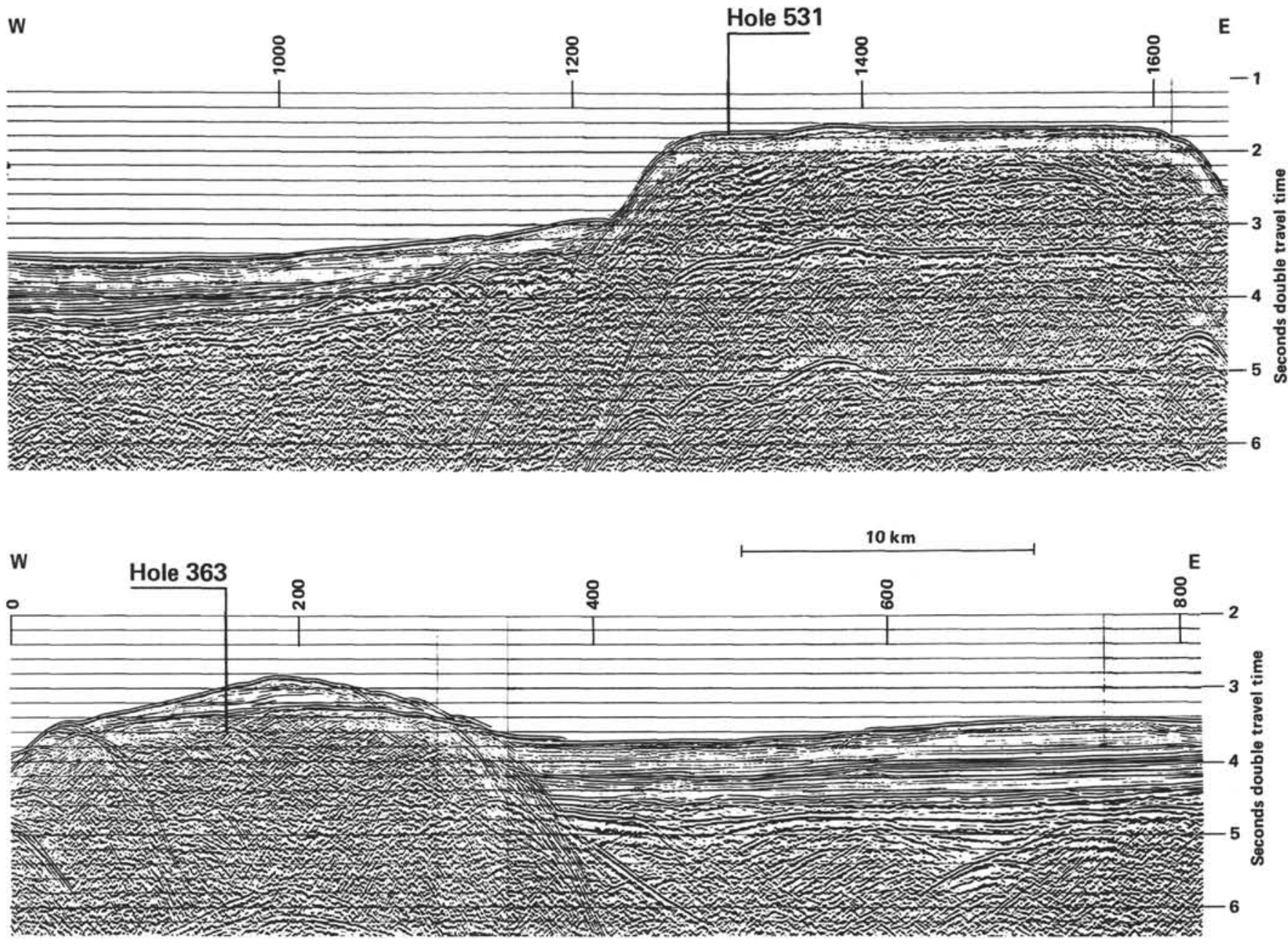

Figure 18. (Continued).

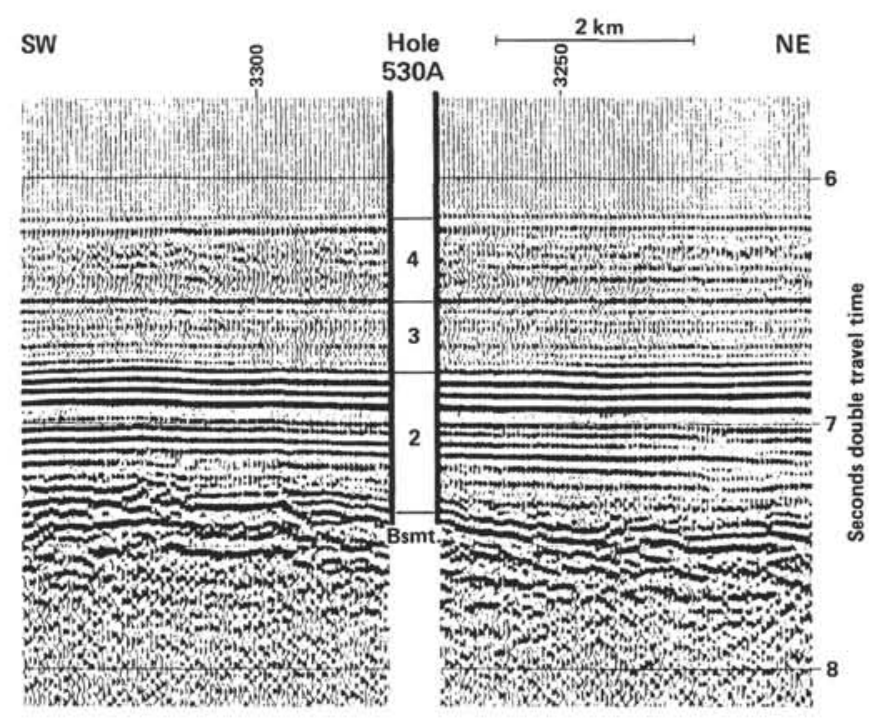

Figure 19. BGR-41 migrated seismic profile in the vicinity of Site 530 (shot point 3275) in the Angola Basin. Location in Figure 2. The main acoustic units are identified as follows: Unit 2, Cenomanian to early Oligocene; Unit 3, early Oligocene to early late Miocene; Unit 4, early late Miocene to present. shows a prominent magnetic edge effect. Several lateral offsets of a few $\mathrm{km}$ to a few tens of $\mathrm{km}$ or of unknown magnitude have been mapped (Fig. 27). In the Cape Basin, magnetic lineations parallel to the coastline have been identified as Anomalies M2 and M4 by Rabinowitz (1976). East of these oceanic anomalies, a north-northeast to northeast trending pattern is probably associated with thinned continental crust. In the Angola Basin, subdued northwest trending lineations exist on the contour map but are more prominent on profiles projected perpendicular to the tracklines (Sibuet et al., in prep.). At present, these magnetic anomaly lineations with more than $100 \mathrm{nT}$ amplitudes cannot be related to any particular anomalies of the standard magnetic anomaly sequence. Most likely, these anomalies belong to the same part of the $M$ sequence as those identified south of the ridge. The result of magnetic studies at Site 530 and of a previous analysis of magnetic anomalies in the southern Angola Basin and Argentine Basin (Cande and Rabinowitz, 1978) show that a ridge jump may have occurred in the late Aptian, explaining the absence of salt in the southern part of the Angola Basin. It is also possible that these anomalies belong to the faint and not well-identified short reversals of the Cretaceous quiet 


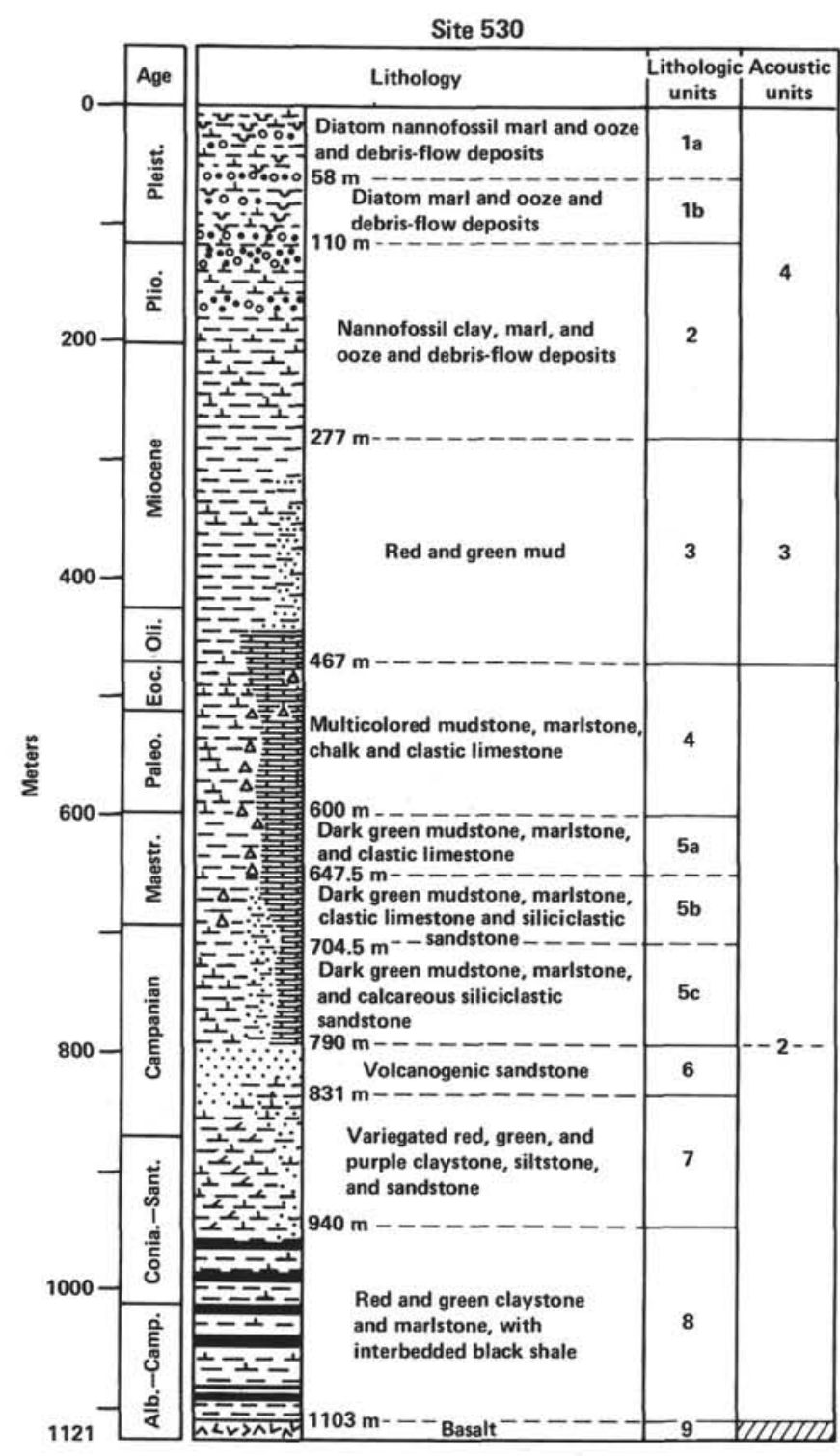

Figure 20. Lithologic column and units correlated with acoustic units at Site 530 in the Angola Basin. (Revisions of stratigraphic ages are given in Steinmetz et al., this volume.)

zone, but their amplitude is larger than is expected by computation.

\section{Gravity Data}

A free-air gravity anomaly map has been prepared using the same data sources as for the magnetic map except that gravity data were not acquired by the $\mathrm{D} / \mathrm{V}$ Glomar Challenger or by the R/V Résolution (Fig. 28). Difference of gravity values at intersections of track lines do not exceed $10 \mathrm{mgal}$, which is a normal error value because reference values are different from one cruise to another and because a cross-coupling error could remain for some data. The contour interval for the map in Fig. 28 is $10 \mathrm{mgal}$. The map was continued on land using the Bouguer anomalies given on the Geological Map of South West Africa (South Africa Geological Survey, 1963). Only a small discontinuity between free-air and

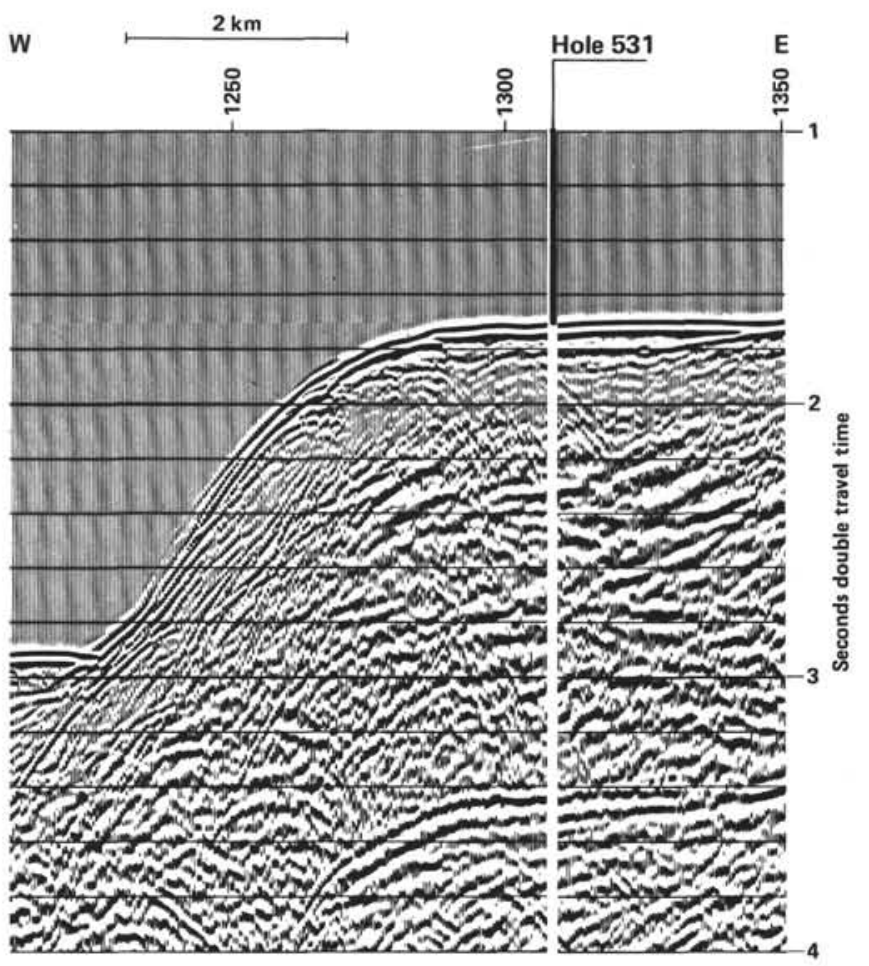

Figure 21. BGR-36 processed seismic line in the vicinity of Site 531 (shot point 1308) on a guyot-like feature of the eastern Walvis Ridge. Location in Figure 2.

Bouguer anomalies should exist at the shore line because the shelf is wide and there is little relief on land.

Strong anomalies with high gradients are associated with bathymetric relief because the free-air anomaly is largely dependent on the bottom topography. Nevertheless, the eastern Walvis Ridge is underlain by a large positive anomaly of about $30 \mathrm{mgal}$, flanked on each side by negative bands $50 \mathrm{~km}$ wide in the deep abyssal plains - a typical edge effect. Gravity values in the abyssal plains are close to zero, which indicates that the basins are in isostatic equilibrium. Goslin and Sibuet (1975) have shown that the ridge is also in local isostatic equilibrium and was consequently emplaced simultaneously with the adjacent oeanic crust. Two-dimensional (Detrick and Watts, 1979) and three-dimensional (Bulot et al., 1982) spectral analyses of the gravity data have confirmed these results. Note that the Walvis Ridge has no gravity extension on land and that the fracture-zone trends are also evident in the gravity data (Fig. 28).

\section{Structural Map of the Walvis Ridge Area}

Based on topography and basement morphology, the Walvis Ridge has been divided into four structural provinces; two additional complementary provinces correspond to the Cape and Angola basins. On seismic sections, provinces 1 and 2 , bounded on the west by the $2,000 \mathrm{~m}$ isobath, are characterized by the presence of parallel internal basement reflectors dipping towards the ocean at angles up to $8^{\circ}$ (Fig. 5) and interrupted by faults every 5 to $10 \mathrm{~km}$. The vertical offset of these faults varies from hundreds of meters (Fig. 10) to kilo- 


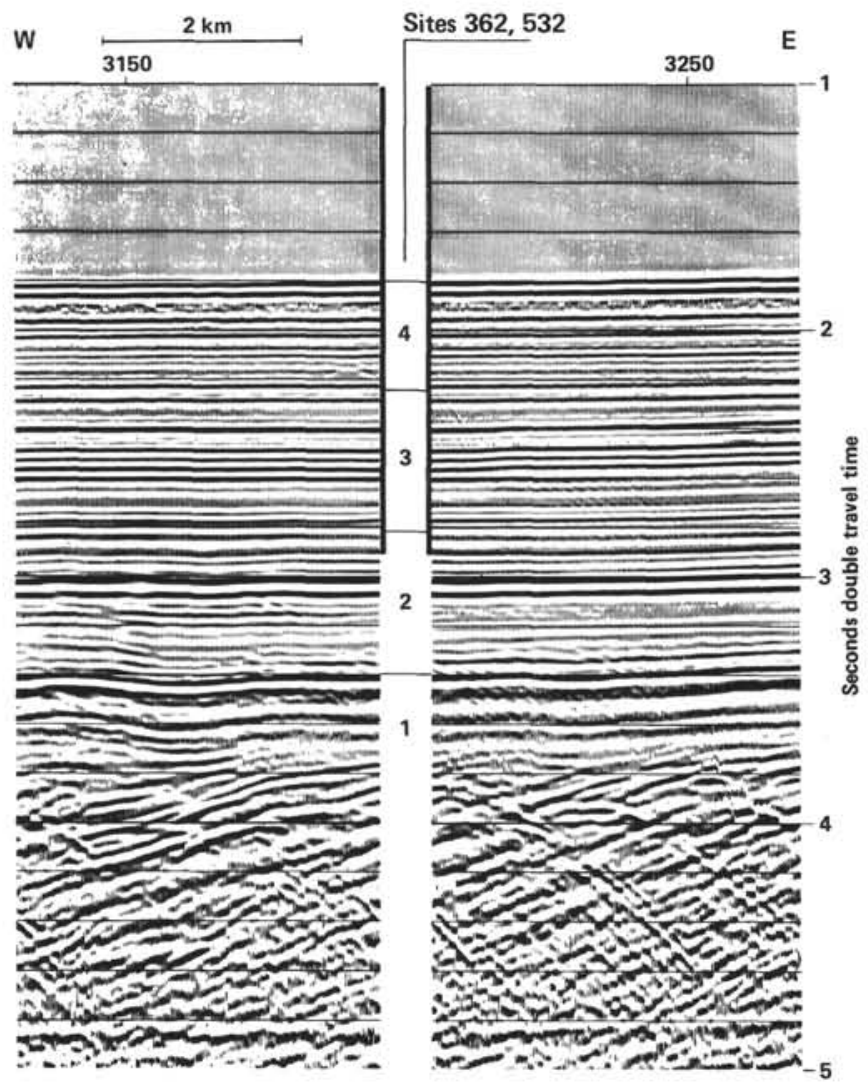

Figure 22. BGR-36 processed seismic line in the vicinity of Sites 362/ 532 (shot point 3200 ) on the eastern Walvis Ridge. Location in Figure 2. The main acoustic units are identified as follows: Unit 1, older than Cenomanian; Unit 2, Cenomanian to early Oligocene; Unit 3, early Oligocene to early late Miocene; Unit 4, early late Miocene to present.

meters (Fig. 5). The density of tracklines allows us to draw approximate faultlines (Fig. 29). These faultlines are grouped into two main directions, $\mathrm{N} 10^{\circ}$ and $\mathrm{N} 60^{\circ}$. The $\mathrm{N} 60^{\circ}$ direction is obvious on the gravity and magnetic maps and corresponds to the general orientation of the Walvis Ridge. In particular, it corresponds to the trend of the northern and southern flanks of the ridge, which is also the trend of the fracture zones in this area (Mascle and Sibuet, 1974). The $\mathrm{N} 60^{\circ}$ faults delimit elongated bands parallel to the ridge. The $\mathrm{N} 10^{\circ}$ faults lie within these bands. The acoustic basement, with its dipping reflectors offset by the faults, suggests that early tensional movements produced tilted fault blocks. The tops of some of the blocks are truncated (Fig. 18). Most of the $\mathrm{N} 10^{\circ}$ faults dip toward the continent (Fig. 29). The axis of the main elongate basin forming the boundary between structural provinces 1 and 2 seems to consist of a series of $\mathrm{N} 10^{\circ}$ en echelon sinistrally offset depressions (Fig. 28). These $\mathrm{N} 10^{\circ}$ structural directions are also present on the southern Angolan margin, although the general trend of this basin and of the isobaths along the southern Angolan margin is $\mathrm{N}$ $350^{\circ}$ (Fig. 1). The eastern flank of the basin is only partly visible on some of the seismic profiles, none of which extends to the coastline. More than $10 \mathrm{~km}$ of sediment fill the $\mathrm{N} 350^{\circ}$ trending depression. The acoustic base-

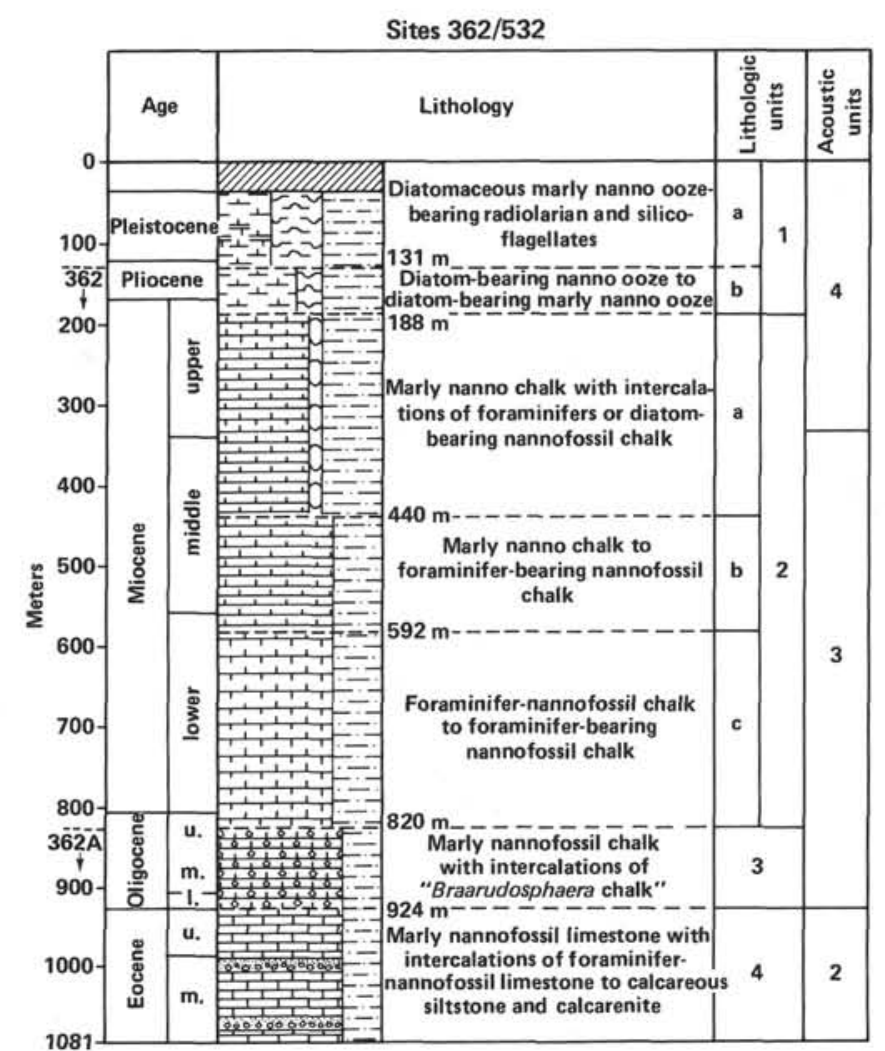

Figure 23. Lithologic column and units correlated with acoustic units at Sites $362 / 532$ on the eastern Walvis Ridge.

ment rises toward the coastline but because of the depth of the acoustic basement no internal reflectors can be seen.

One of the initial objectives of Leg 75 sites on the Walvis Ridge was to determine the lithologies of the dipping reflectors which have also been observed in other areas, including the continental margins of Antarctica, East Greenland, Rockall, the Vøring Plateau, and in the Lofoten and Wharton basins. We wanted to understand the nature and significance of basement with dipping reflectors adjacent to oceanic basement such as that dredged on the top of the northern flank of the ridge (Hékinian, 1972). We also wanted to know if there were any differences in the processes of formation of an aseismic ridge anchored to a continent rather than locked to the adjacent typical oceanic crust.

Because of safety limitations, the initial Site SAI-4 which had been proposed to drill into these dipping reflectors was moved to the location of Site 531, where dipping reflectors outcrop nearby. Unfortunately, the bottom was firm and could not be penetrated by the drill. The problem of the nature of internal oceanward dipping reflectors in this structural setting has been particularly addressed during DSDP Leg 81 on the Rockall margin. Drilling through the sequence of dipping reflectors allowed Roberts, Schnitker et al. (1982) to interpret them as a voluminous eruption of basic flows and tuffs with possible thin sedimentary interbeds. The deposition of these rocks took place during rifting in a shallow marine to subaerial environment. The divergent form of 


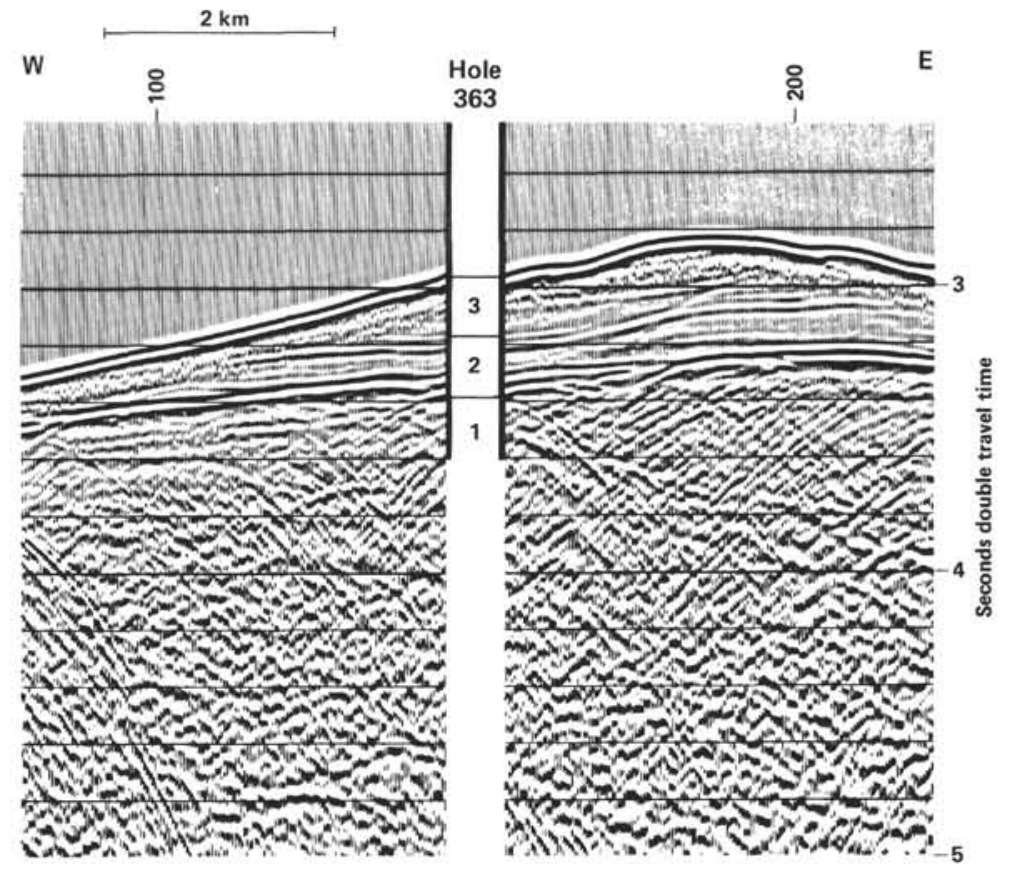

Figure 24. BGR-36 processed seismic line in the vicinity of Site 363 (shot point 150 ) on the northern flank of the eastern Walvis Ridge. Location in Figure 2. The main acoustic units are identified as follows: Unit 1, older than Cenomanian; Unit 2, Cenomanian to early Oligocene; Unit 3, early Oligocene to early late Miocene.

the dipping reflectors toward the ocean in the Rockall area has been interpreted as resulting from the subsidence associated with an increase in rate of crustal extension simultaneous with the occurrence of volcanics. On the eastern Walvis Ridge such divergent reflectors do not exist. This suggests that if the dipping reflectors are mainly within a volcanic sequence, these volcanics could have been emplaced either rapidly or during a longer time in a uniform extensional or quiet context.

The structural map, Figure 23, shows that fracturing played an important role during the formation of provinces 1 and 2 and that the dipping reflectors cannot be interpreted simply as volcanic emissions in a slope environment. The structural pattern, morphology of the blocks, and presence of the $\mathrm{N} 350^{\circ}$ basin rather suggest that tensional stresses have modified a previously stratified sequence. This initial sequence may have been continental crust overlain by a sedimentary sequence or, more probably, by an intercalation of sediments and volcanics associated with the probable Jurassic lavas that were drilled on the South African continental shelf and which have a certain but unknown regional extent (Gerrard and Smith, 1983). Davis (1982) has shown that on a slope of only 1 per 1,000 a submarine basaltic flow initially $3 \mathrm{~m}$ thick could extend $20 \mathrm{~km}$ if it had an initial temperature of $1150^{\circ} \mathrm{C}$ and $80 \mathrm{~km}$ if it had an initial temperature of $1250^{\circ} \mathrm{C}$. This suggests that massive independent volcanic flows and tuffs with possible interbedded sedimentary layers could have been emplaced not only in a subaerial environment as suggested by Mutter et al. (1982) but also under submarine conditions (Roberts, Schnitker et al., 1982). Then the resulting stratified sequence could have been affected by later extensional tectonics, so that the resulting broken basement resembles that of the continental margins of North Biscay (Le Pichon and Sibuet, 1981) and West Iberia (Sibuet et al., 1982) formed at the end of the Early Cretaceous rifting episode. As the maximum of extension probably corresponds to the deeper part of the $\mathrm{N} 350^{\circ}$ trending depression, blocks must have been tilted inward toward the edges of the $\mathrm{N} 350^{\circ}$ depression as predicted by Le Pichon and Sibuet (1981). This is clearly shown on the structural map where faults face the axis of the $\mathrm{N} 350^{\circ}$ depression. The consequence of this hypothesis is an increase of the initial dip of the internal basement reflectors westward in structural province 2 , while this angle is reduced in structural province 1 .

\section{Discussion of Structural Provinces}

\section{Structural Province 1 (Fig. 29)}

Structural province 1 is limited on the east by the coastline and on the west by the axis of the $\mathrm{N} 350^{\circ}$ trending basin which lies approximately beneath the $500-\mathrm{m}$ isobath. It corresponds mostly to the continental shelf and is about $100 \mathrm{~km}$ wide (Fig. 1). It also corresponds to the $10 \mathrm{mgal}$ anomaly contour. Weak positive gravity anomalies (Fig. 28) associated with magnetic anomalies (Fig. 27) are observed in geologic province 1 and are related to isolated structures (Goslin and Sibuet, 1975). There are too few multichannel seismic and geophysical profiles to define in detail the deep structure of province 1 and in particular the nature and morphology of the acoustic basement. 
Site 363

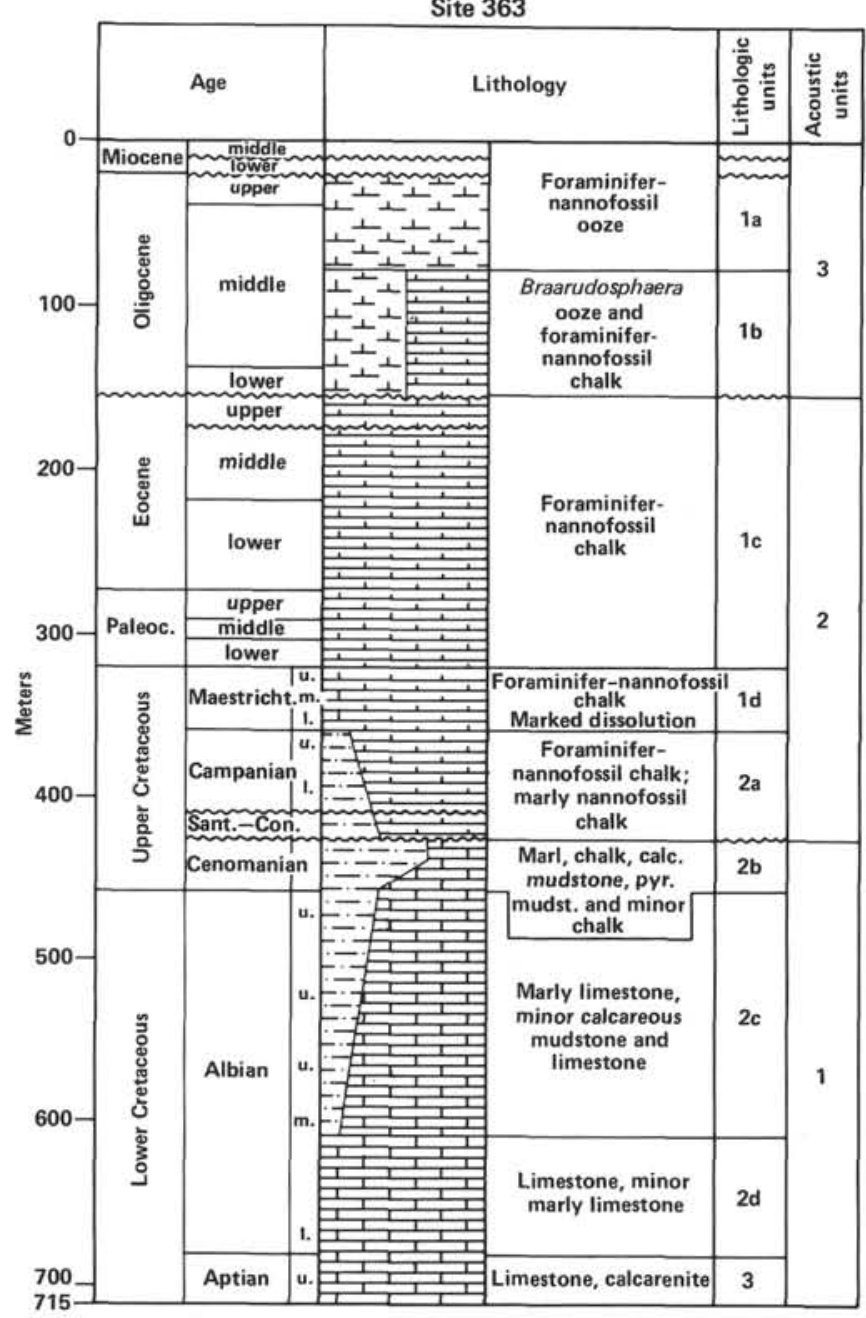

Figure 25. Lithologic column and units correlated with acoustic units at Site 363 on the northern flank of the eastern Walvis Ridge.
Structural Province 2 (Fig. 29)

Structural province 2 is limited on the east by the axis of the $\mathrm{N} 350^{\circ}$ trending depression and on the west by the western limit of the oceanward dipping reflectors within acoustic basement, which lies approximately beneath the 2,000-m isobath. The northern limit of this province corresponds to the northern flank of the ridge, but the southern limit is far south of the eastward projection of the southern flank of the ridge, extending to about $21.5^{\circ} \mathrm{S}$. This province is also distinctive on the magnetic and gravity anomaly maps, which probably reflect differences in the nature of basement between province 2 and the basement of the adjacent province 3 . We propose that the basement morphology was acquired during a tensional phase affecting stratified volcanics overlying sediments or continental crust.

\section{Structural Province 3 (Fig. 29)}

Structural province 3 is the central plateau of the eastern Walvis Ridge and is limited on the west by the 2,250-m isobath. Its northern and southern limits are the northern and southern flanks of the ridge. The width of this province is considerably less than that of province 2 (Fig. 29). The western boundary indicated on the bathymetric and gravity map marks the position where the Walvis Ridge increases in width. The acoustic basement appears to be exclusively volcanic, with no dipping reflectors. Near province 2 , the presence of interstratified volcanic flows within the sediments is interpreted as a Late Cretaceous eruptive phase.

\section{Structural Province 4 (Fig. 29)}

Structural province 4 joins the western part of the eastern Walvis Ridge to the north-south trending segment which contains the Valdivia Bank. This province is marked by an offset of the Walvis Ridge to the south

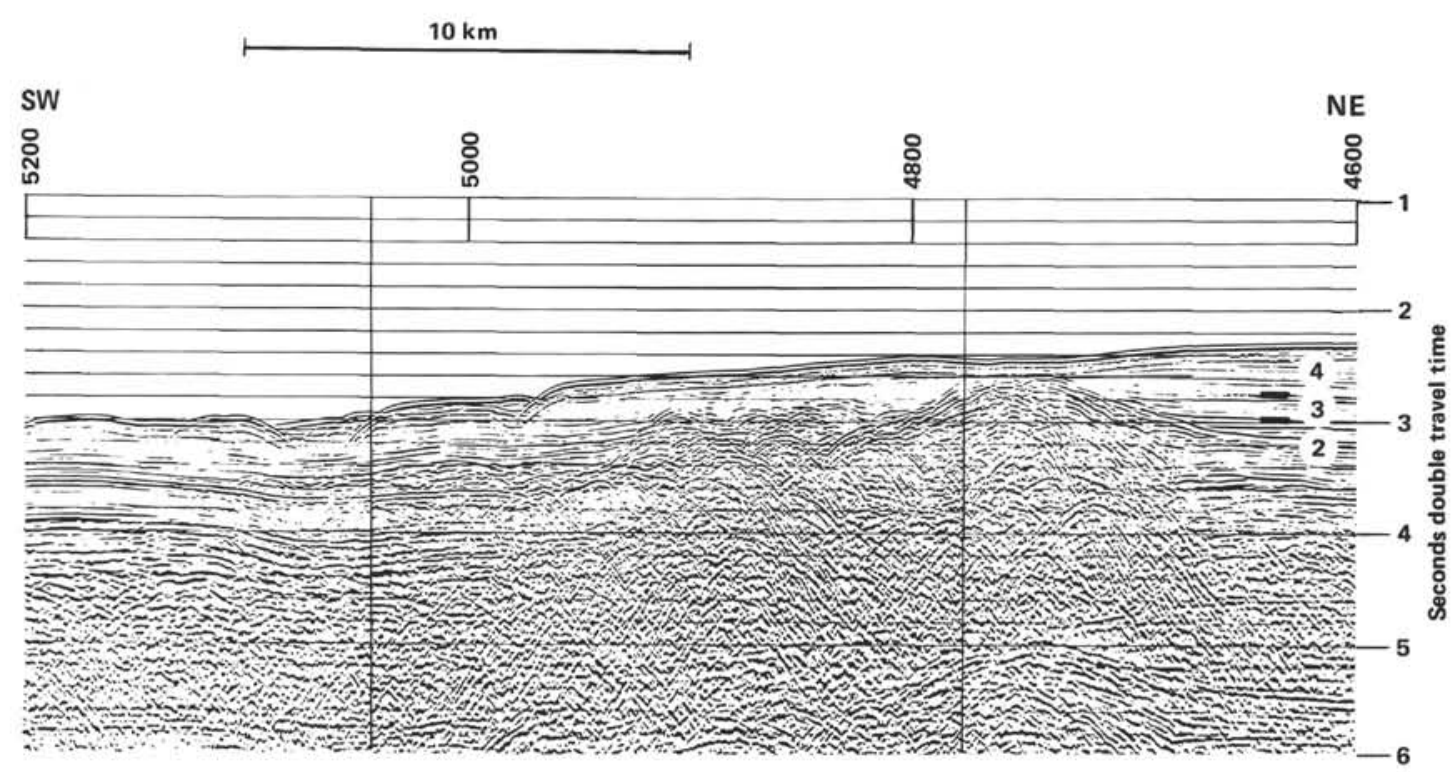

Figure 26. BGR-37 processed seismic profile showing the probable Late Cretaceous volcanism intercalated within the sediments. Location in Figure 2. The main acoustic units are identified: Unit 2, Cenomanian to early Oligocene; Unit 3, early Oligocene to early late Miocene; Unit 4, early late Miocene to present. 


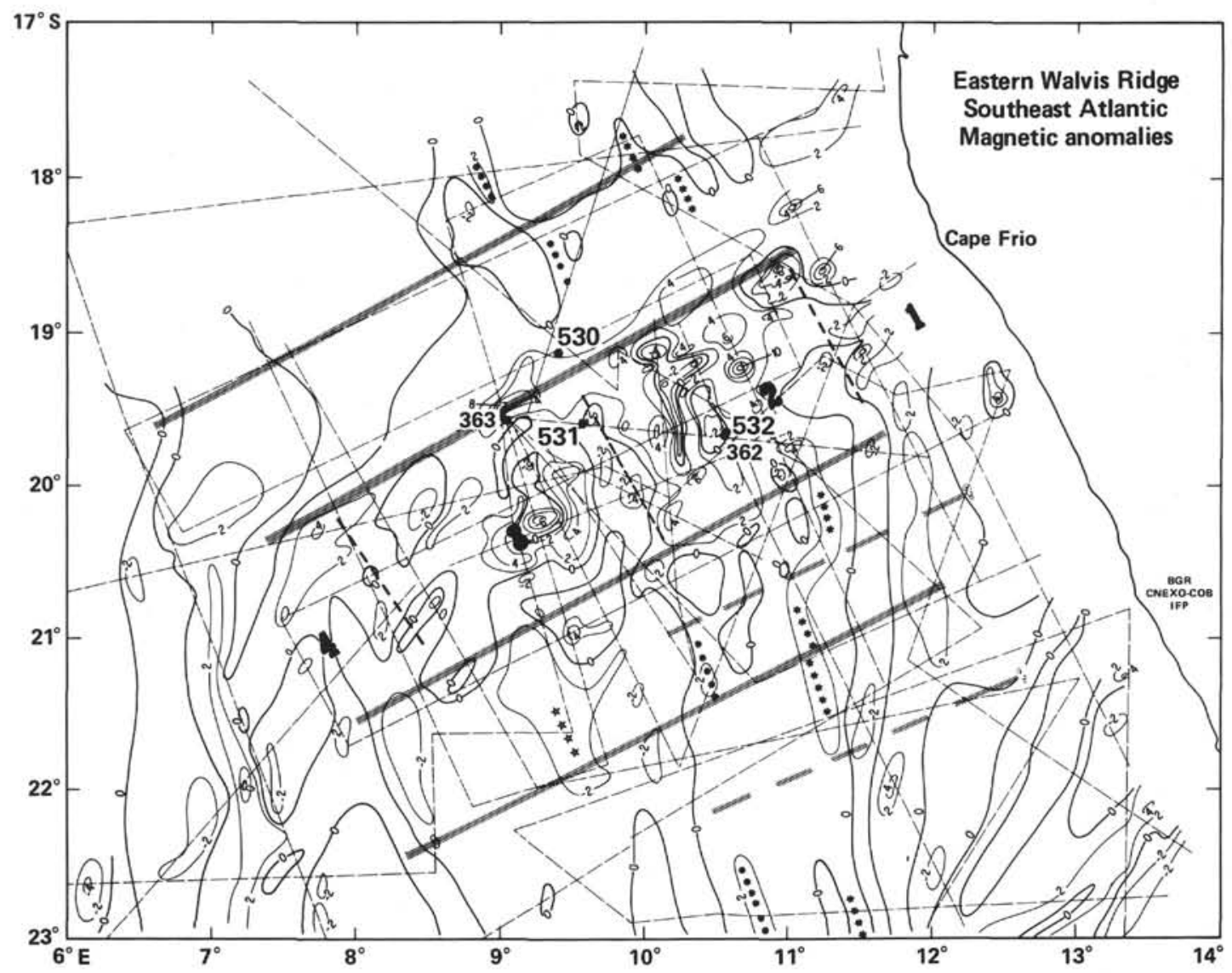

Figure 27. Magnetic anomaly map of the eastern Walvis Ridge. Contour interval is $200 \mathrm{nT}$. Tracklines in dashed lines. Hatchures correspond to inferred fracture zones and stars to magnetic lineations. The four main provinces on the ridge are identified and separated by heavy dashed lines.

and an inversion of relief. Magnetic anomalies are similar to those of the adjacent typical ocean crust (Fig. 27).

\section{Principal Stages of the Structural Evolution}

From these observations and conclusions we propose a scheme for the structural evolution of the eastern Walvis Ridge based on the hypothesis that structural provinces 1 and 2 are of continental origin. Three observations support this hypothesis: (1) The seismic structure of the acoustic basement reflects a tensional phase which affected an initial continental crustal block probably capped by interbedded volcanic and sedimentary layers. The tilted fault blocks (e.g., Fig. 5) allow us to compute a tensional stretching factor of 1.2 , which is less than the theoretical value of the stretching factor of 1.3 if we suppose that the continental crust was initially at sea level (LePichon and Sibuet, 1981). (2) Structural provinces 1 and 2 have unique bathymetric, magnetic, gravimetric, and seismic characteristics. In particular, gravity modelling of a profile, along the axis of the Walvis Ridge, shows that for models in isostatic equilibrium and for reasonable values of crustal density there is a difference of 2 to $3 \mathrm{~km}$ in the thickness of the crust on each side of the boundary between structural provinces 2 and 3 (Sibuet et al., this volume). (3) In terms of kinematic reconstructions, a gap exists just south of the São Paulo plateau that corresponds to the spur formed by provinces 1 and 2 of the eastern Walvis Ridge (Sibuet et al., this volume).

\section{Origin of Structural Provinces 1 and 2}

During the Late Jurassic (Oxfordian-Kimmeridgian), tensional stresses affected the band of crust which became the South American and African continental margins (Figure 30A). The crust was progressively thinned, particularly in the area of structural provinces 1 and 2 and their South American counterpart (Fig. 30B). The axis of this rift zone was the $\mathrm{N} 350^{\circ}$ trending depression, which is the natural prolongation of the Namibia and Angola continental margins. The brittle continental crust was broken by faults striking $\mathrm{N} 10^{\circ}$ and dipping into the axis of the depression. Tilted fault blocks were created in the upper stratified continental crust, thereby producing the oceanward dipping reflectors west of the axis of the $\mathrm{N} 350^{\circ}$ depression. The end of this tensional phase occurred before late Aptian time, because limestone and calcarenites of late Aptian age have been drilled at Site 363 in structural province 3 . During this phase some of the blocks may have been exposed to subaerial erosion, producing the flat tops observed on many of the blocks.

\section{Formation of Eastern Part of Structural Province 3}

The formation of structural province 3 began after the locus of maximum thinning jumped from the $\mathrm{N}$ 


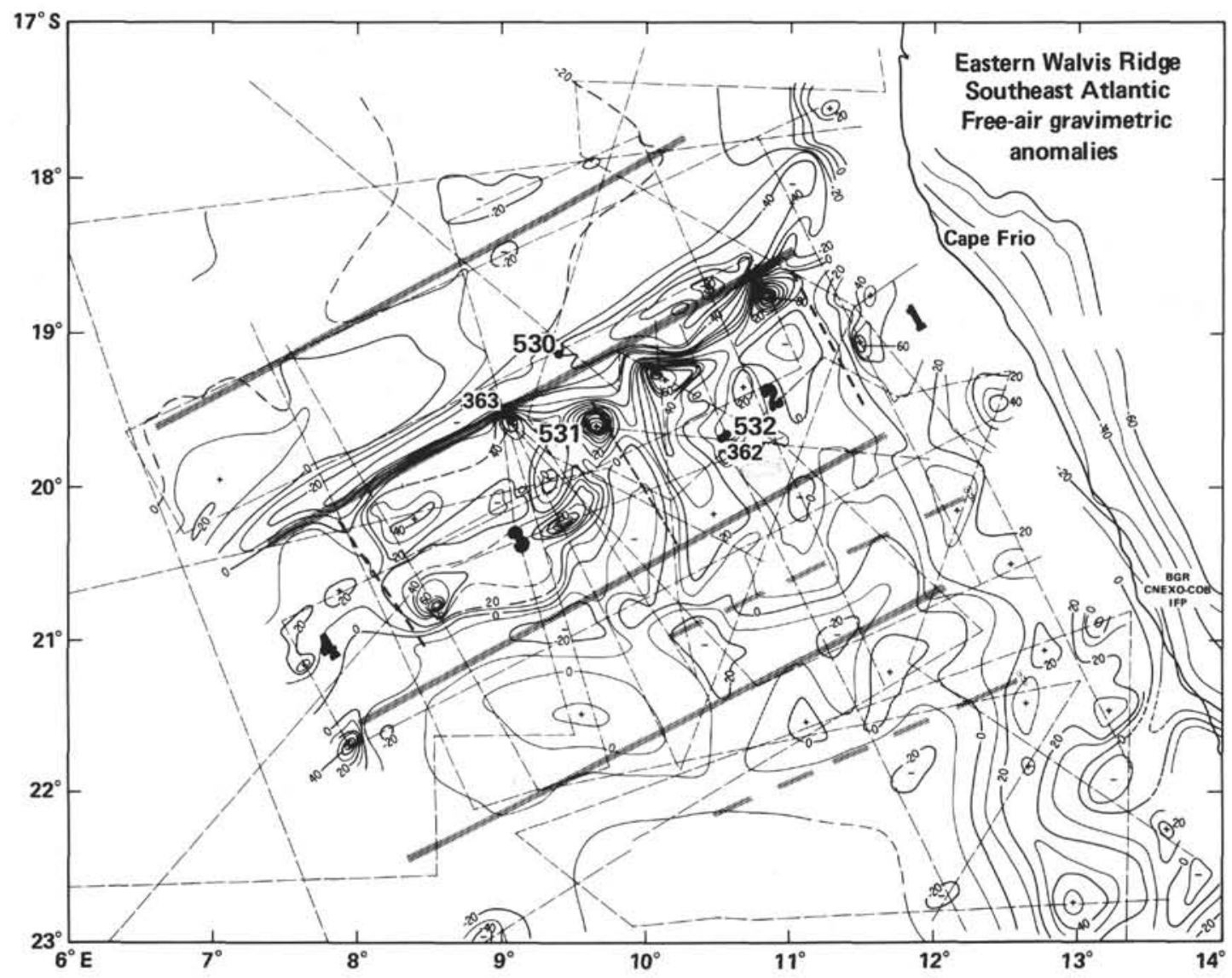

Figure 28. Free-air gravity anomaly map of the eastern Walvis Ridge. Contour interval is $10 \mathrm{mgal}$. Bouguer anomalies on land (South Africa Geological Survey, 1963). Tracklines in dashed lines. Hatchures correspond to inferred fracture zones. The four main structural provinces on the Ridge are identified and separated by heavy dashed lines.

$350^{\circ}$ trending depression to the boundary between provinces 2 and 3 (Fig. 30C). The abnormal oceanic basement of province 3 was emplaced either close to sea level, as shown by the fragments of late Aptian shallowwater calcareous algae found in the massive limestones at Site 363 , or in a subaerial environment as suggested by the presence of probable erosion surfaces (Fig. 30D). Less thinning of continental lithosphere is necessary to reach a lithostatic level of emplacement of oceanic crust close to sea level, as has been demonstrated in the Afar region. A stretching factor of about three is required to reach a mean water depth of $2.5 \mathrm{~km}$ for emplacement of oceanic crust at the foot of continental margins (LePichon and Sibuet, 1981). At least part of the oceanic crust of province 3 may have been emplaced before any oceanic crust formed in the adjacent basins (Fig. 30D).

\section{Formation of Western Part of Structural Province 3, Structural Province 4, and the Adjacent Oceanic Basins}

Oceanic crust began to be emplaced both south and north of the Walvis Ridge during Barremian-early Aptian times as has been proposed by Rabinowitz (1976) and Cande and Rabinowitz (1978), who have identified magnetic Anomalies M4 south of the ridge and M3 (?) north of the ridge on the South American side (Fig. 30E).

A ridge jump occurred during the late Aptian-early Albian in the southern part of the Angola Basin; this translated the previously formed oceanic crust and its overlying salt deposits to the South American side (Cande and Rabinowitz, 1978; Site 530 chapter, this volume, and this study, Fig. 30F). Then new oceanic crust was created, starting probably in the vicinity of the continent/ocean boundary of the Angola continental margin. The Cape Basin and the Walvis Ridge continued to grow (Fig. 30G). The boundary between structural provinces 3 and 4 probably corresponds to a major change in the mode of formation of the ridge from the construction of a large oceanic crustal pile between two close fracture zones defining the northern and southern flanks to an accretionary spreading center located between two fracture zones separated by $500 \mathrm{~km}$ and defining the northern and southern ends of the N-S segment of Walvis Ridge. Several ridge jumps occurred on both sides of the Walvis Ridge (Sibuet, in prep.) during the Cretaceous and early Tertiary producing a 500-km-long segment of mid-oceanic ridge without any significant offset.

Note that in this model a fracture zone must exist in the Angola Basin at the foot of the Walvis Ridge and must have an offset of up to $150 \mathrm{~km}$. If this is true, the Walvis Ridge was emplaced just before the adjacent basins; this would explain both the fact that the eastern Walvis Ridge and its adjacent basins are in local isostatic equilibrium and the fact that seismic profiles perpendicular to the Walvis Ridge indicate that the Angola 


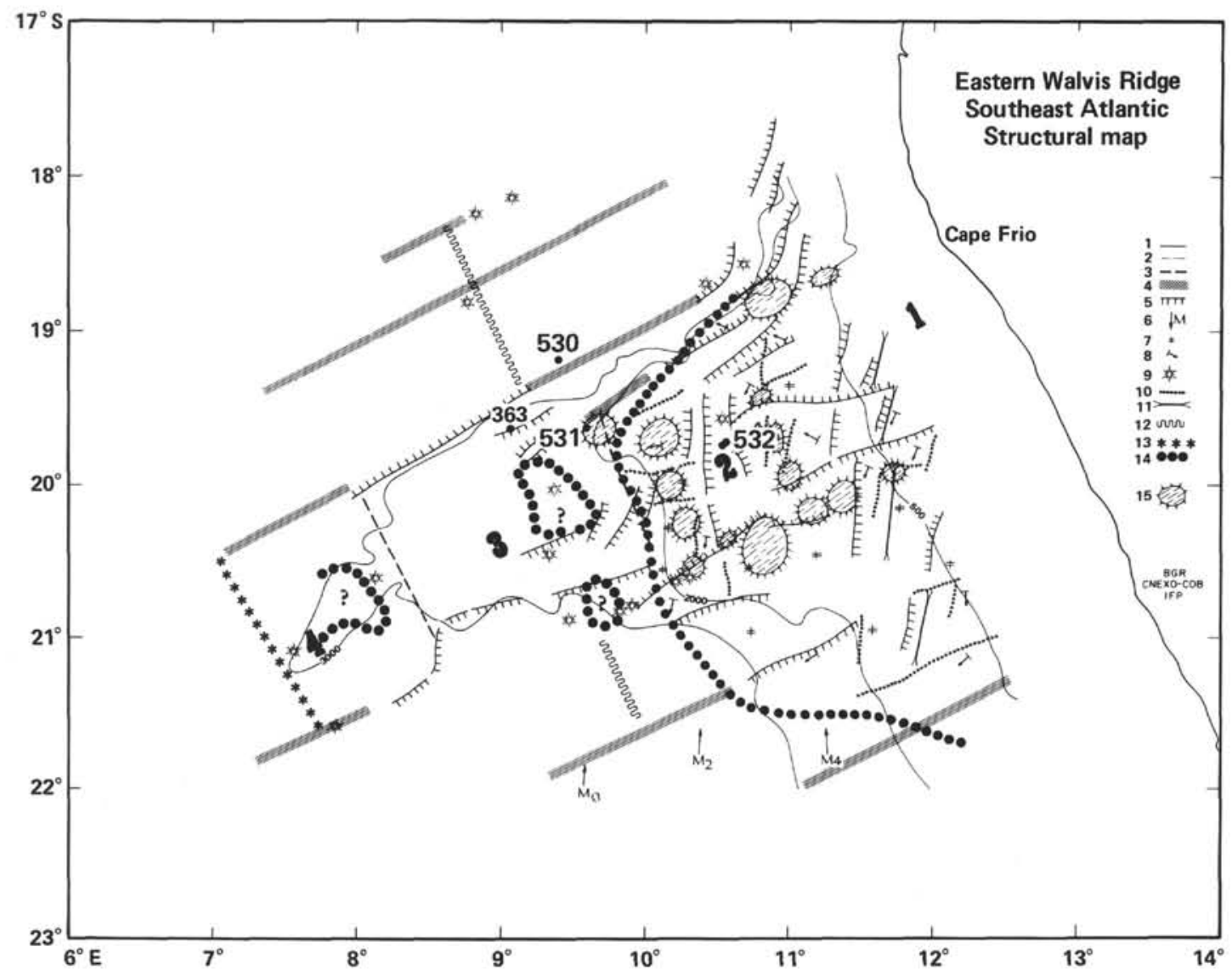

1) Main isobaths. 2) Trackline control. 3) Boundaries between the four main structural provinces of the ridge. 4) Fracture zones. 5) Faults 6) Identified magnetic anomalies. 7,8) Dip of subacoustic basement reflectors. 9) Major volcanic features in the basement topography. 10) Direction of structural lines deduced from deep basement reflectors. 11) Axis of the depression located at the boundary between structural provinces 1 and 2. 12) Western boundary of pre-Cenomanian deposits. 13) Western boundary of the pre-Campanian deposits. 14) Limit of occurrence of deep basement reflectors. 15) Eroded surfaces or sites of nondeposition.

Figure 29. Structural map of the eastern Walvis Ridge.

Basin has been subsiding faster than the Walvis Ridge (Musgrove and Austin, this volume). Thus, the basement slopes, divergent reflectors, and basinward prograding clinoforms of acoustic Unit 2 can be interpreted as resulting from the different subsidence rate of two adjacent oceanic crusts of different age (e.g., Sibuet and Veyrat-Peinet, 1980).

\section{CONCLUSION}

Analysis of data obtained by drilling during Legs 40 and 75 of the D/V Glomar Challenger, and interpreted in the framework of multichannel surveys planned both to define Leg 75 drill sites and to outline the early stages of the South Atlantic evolution, has established the seismic stratigraphy of the region and suggests a new model of the structural and sedimentary evolution of the eastern Walvis Ridge and adjacent basins.

The acoustic stratigraphy established in the Walvis Ridge and southern Angola Basin areas has been calibrated by DSDP holes drilled at Sites 530, 531, 362/532, and 363.

Acoustic Unit 1 has not yet been drilled with certainty in the Angola Basin but, based on estimation of the mean thickness of sediments belonging to this unit at the Angola continent/ocean boundary compared to the mean relative sedimentation rate, an oldest age for the oceanic crust of late Aptian/early Albian is expected. Acoustic Units 2 to 4 are well correlated with lithostratigraphic data in the Angola Basin.

Acoustic units 3 and 4 are well correlated with lithostratigraphic units on the Walvis Ridge and adjacent shelf area. The base of acoustic Unit 2 (Cenomanian) is not well defined at Site 363, and therefore cannot be correlated over the whole area. In the sedimentary basin on the ridge, the base of Unit 2 is inferred on the basis of mean relative sedimentation rate. Because of uncertainties regarding the identification of the Cenomanian reflector on the Walvis Ridge, we only present isopach maps of acoustic Units 3 and 4 for the whole area.

Four structural provinces can be recognized on the eastern Walvis Ridge, numbered 1 through 4 from east to west. The two easternmost provinces, 1 and 2, form the junction of the Walvis Ridge with the continental margin and have a basement of thinned continental crust. They are separated by a $\mathrm{N} 350^{\circ}$ trending depression and are characterized by thick sediment cover and internal basement reflectors which, in the western of the two provinces, 2 , dip oceanward. The remainder of eastern Walvis Ridge comprises two structural provinces, 3 and 4 , having an oceanic basement and thinner sedi- 


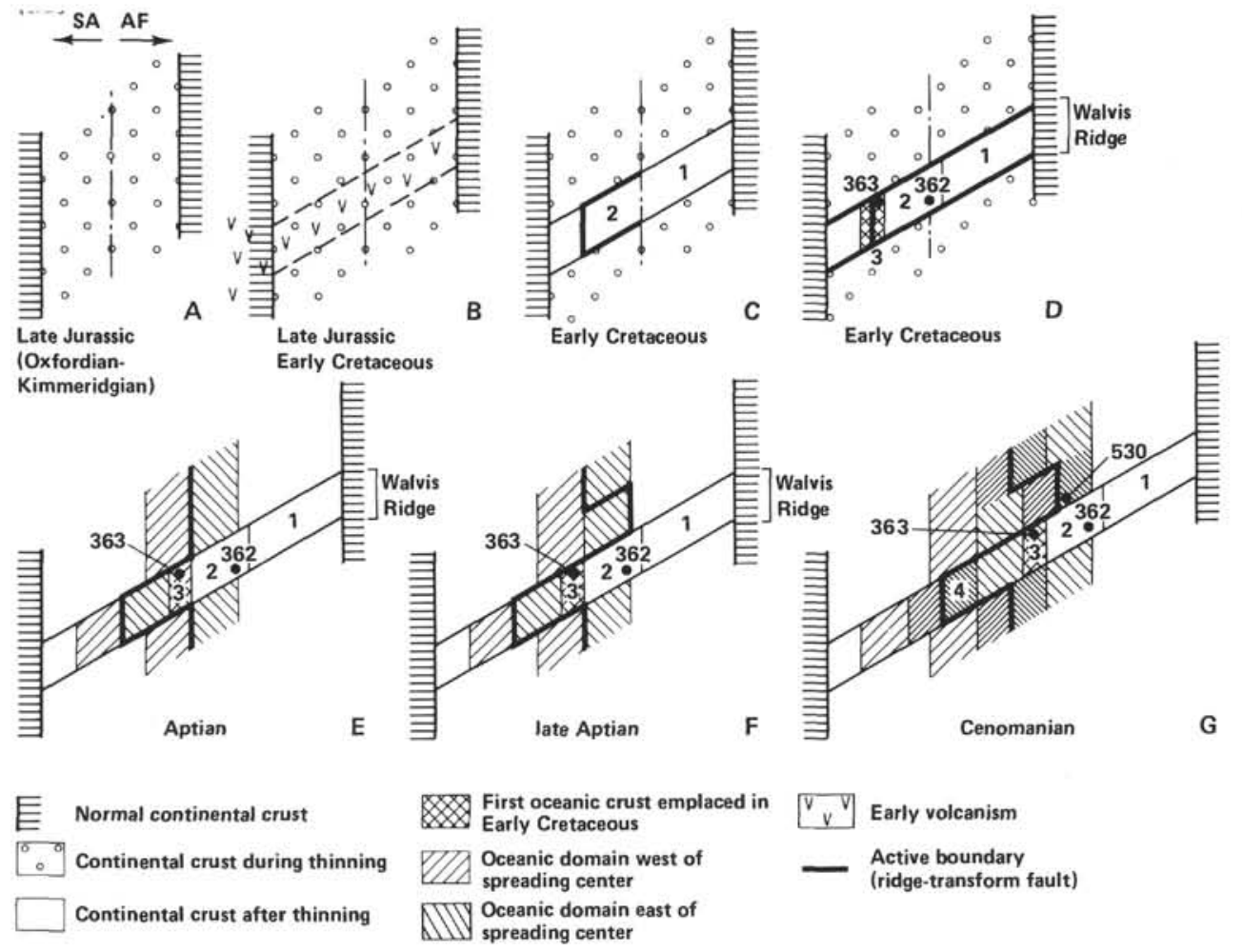

Figure 30. Schema of the evolution of the eastern Walvis Ridge and adjacent basins (see text for detailed explanations).

ment cover. Structural province 3 is the central plateau of the eastern Walvis Ridge and province 4 to its west abuts the N-S trending segment of Walvis Ridge that includes Valdivia Bank. Structural provinces 1 and 2 represent the two sides of an early rift resulting from thinning of the continental crust and are underlain by eastward and westward dipping tilted fault blocks, respectively. Structural province 3 represents abnormal oceanic crust, emplaced near sea level before the ridge jumped eastward in the adjacent Angola Basin, translating the evaporite deposits to the South American side of the young ocean basin. Structural province 4 was formed after the ridge jump and corresponds to a major change in the mode of formation of oceanic crust, from construction of an oceanic crustal pile between two closely spaced fracture zones bordering the northern and southern flanks of the eastern segment of Walvis Ridge to an abnormal accretionary spreading center located between two fracture zones separated by $500 \mathrm{~km}$, forming the northern and southern ends of the N-S segments of Walvis Ridge.

\section{ACKNOWLEDGMENTS}

The authors are especially indebted to the crews and scientific teams of the R/V Jean Charcot (Centre National pour l'Exploitation des Océans), R/V Résolution (Institut Français du Pétrole) and R/V Explora (Bundesanstalt für Geowissenschaften und Rohstoffe) who participated in the geophysical and geological cruises, and to the Centre National pour l'Exploitation des Océans, the Institut Français du Pétrole, the Comité d'Etudes Pétrolieres Marines and the Bundesanstalt für Geowissenschaften und Rohstoffe for financial support. We gratefully acknowledge Walter Dean and Eric Barron who critically reviewed and improved the manuscript and offered helpful suggestions.
We thank Daniel Carré for preparing the illustrations. This is contribution 832 of the Centre Océanologique de Bretagne.

This work is dedicated to the late Professor E. S. W. Simpson who died suddenly in June 1983. Among his many contributions to the earth sciences, his pioneer work in establishing bathymetric and geological syntheses of the ocean floor surrounding Southern Africa has been for many years the principal reference for planning and conducting oceanographic cruises in this area of the world.

\section{REFERENCES}

Barnaby, A. M., 1974. The structure of the eastern Walvis Ridge and the adjacent continental margins [Unpubl. M. Sc. dissert]. University of Cape Town, South Africa.

Bolli, H. M., Ryan, W. B. F., Foresman, J. B., Hottman, W. E., Kagami, H., Longoria, J. F., McKnight, B. K., Melguen, M., Natland, J., Proto-Decima, F., and Siesser, W. G., 1978. Walvis Ridge-Sites 362 and 363. In Bolli, H. M., Ryan, W. B. F., et al., Init. Repts. DSDP, 40: Washington (U.S. Govt. Printing Office), 183-356.

Bullard, E. C., Everett, J. E., and Smith, A. C., 1965. The fit of the continents around the Atlantic. In Blackett, P. M. S., Bullard, E., and Runcorn, S. K. (Eds.), A Symposium on Continental Drift. Philos. Trans. R. Soc. London, 258A:41-51.

Bulot, A., Diament, M., Kogan, M., and Kostoglodov, V., 1982. Isostasy of oceanic area: A three dimensional spectral analysis approach. EOS, 63:1280.

Cande, S., and Rabinowitz, P. D., 1978. Mesozoic seafloor spreading bordering conjugate continental margins of Angola and Brazil. Proc. Offshore Tech Conf., Rep. OTC 3268, Houston, Tex., 1869-1876.

Davis, E. E., 1982. Evidence for extensive basalt flows on the sea floor. Geol. Soc. Am. Bull., 93:1023-1029.

Detrick, R., and Watts, A. B., 1979. An analysis of isostasy in the world's oceans: 3, Aseismic ridges. J. Geophys. Res., 84: 3637-3635.

Dietz, R. S., and Holden, J. C., 1970. Reconstruction of Pangaea: Breakup and dispersion of continents, Permian to present. J. Geophys. Res., 75:4939-4956. 
Emery, K. O., Phillips, J., Bowin, C., and Mascle, J., 1975. Continental margin off western Africa: Angola to Sierra Leone. Am. Assoc. Pet. Geol. Bull., 59:2209-2265.

Ewing, M., Le Pichon, X., and Ewing, J., 1966. Crustal structure of the mid-ocean ridges. 4. Sediment distribution in the South Atlantic Ocean and the Cenozoic history of the Mid-Atlantic Ridge. $J$. Geophys. Res., 71:1611-1635.

Francheteau, J., and Le Pichon, X., 1972. Marginal fracture zone as structural framework of continental margins in the South Atlantic Ocean. Am. Assoc. Pet. Geol. Bull., 56:991-1007.

Gerrard, I., and Smith, G. C., 1983. The post Paleozoic succession and structure of the south-western African continental margin. In Watkins, J. S., and Drake, C. L. (Eds.), Studies in Continental Margin Geology. Am. Assoc. Pet. Geol. Mem., 34:49-76.

Goslin, J., Mascle, J., Sibuet, J.-C., and Hoskins, H., 1974. Geophysical study of the easternmost Walvis Ridge, South Atlantic: Morphology and shallow structure. Geol. Soc. Am. Bull., 85:619-632.

Goslin, J., and Sibuet, J.-C., 1975. Geophysical study of the easternmost Walvis Ridge, South Atlantic: Deep structure. Geol. Soc. Am. Bull., 86:1713-1724.

Hay, W. W., Sibuet, J.-C., Barron, E., Boyce, R. E., Brassell, S., Dean, W. E., Huc, A. Y., Keating, B. H., McNulty, C. L., Meyers, P. A., Nohara, M., Schallreuter, R. E., Steinmetz, J. C., Stow, D., and Stradner, H., 1982. Sedimentation and accumulation of organic carbon in the Angola Basin and on Walvis Ridge: Preliminary results of Deep Sea Drilling Project Leg 75. Geol. Soc. Am. Bull., 93:1038-1050.

Heezen, B. C., and Tharp, M., 1978. General Bathymetric Chart of the Oceans (GEBCO), 5-12: Ottawa, Canada (Canadian Hydrographic Service).

Hékinian, R., 1972. Volcanics from the Walvis Ridge. Nature, 239: 91-93.

Hinz, K., 1981. A hypothesis on terrestrial catastrophes: Wedges of very thick oceanward dipping layers beneath passive continental margins-their origin and paleoenvironmental significance. Geol. J., 22:3-28.

Le Pichon, X., and Hayes, D. E., 1971. Marginal offsets, fracture zones and the early opening of the South Atlantic. J. Geophys. Res., 76:6283-6296.

Le Pichon, X., and Sibuet, J.-C., 1981. Passive margins: A model of formation. J. Geophys. Res., 86:3708-3720.

Mascle, J., and Sibuet, J.-C., 1974. New pole for early opening of South Atlantic. Nature, 252:464-465.

Matthews, D. J., 1939. Tables of the Velocity of Sound in Pure Water and Sea Water for Use in Echosounding and Sound Ranging: Admiralty, London (Hydrographic Department).

Maxwell, A. E., Von Herzen, R. P., Hsü, K. J., Andrews, J. E., Saito, T., Percival, S. F., Milow, E. D., Jr., and Boyce, R. E., 1970. Deep sea drilling in the South Atlantic. Science, 168:1047-1059.

Morgan, W. J., 1971. Convection plumes in the lower mantle. Nature, 230:42-48.

1972. Deep mantle convection plumes and plate motions. Am. Assoc. Pet. Geol. Bull., 56:203-213.
Mutter, J. C., Talwani, M., and Stoffa, P. L., 1982. Origin of seawarddipping reflectors in oceanic crust off the Norwegian margin by "subaerial sea-floor spreading." Geology, 10:353-357.

Pastouret, L., and Goslin, J., 1974. Middle Cretaceous sediments from the eastern part of Walvis Ridge (South Atlantic). Nature, 248:495-496.

Payton, C. E. (Ed.), 1977. Seismic Stratigraphy-Applications to Hydrocarbon Exploration. Am. Assoc. Pet. Geol.

Prunier, A., 1980. Sédimentologie et structure de la partie orientale de la ride de Walvis (Atlantique Sud) à partir des profils de sismique réflexion: Strasbourg, France (Diplome Institut de Physique du Globe).

Rabinowitz, P. D., 1976. A geophysical study of the continental margin of southern Africa. Geol. Soc. Am. Bull., 87:1643-1653.

Roberts, D. G., Schnitker, D., Backman, J., Baldauf, J. G., Desprairies, A., Homringhausen, R., Huddlestun, P., Kaltenback, A. J., Keene, J. B., Krumsiek, K. A. O., Morton, A. C., Murray, J. W., Westberg-Smith, J., and Zimmerman, H. B., 1982. North Atlantic Leg 81 drills west margin Rockall Plateau. Geotimes, 9: 21-23.

Sibuet, J.-C., Amortila, P., Foucher, J.-P., and Le Pichon, X., 1982. Tilted fault blocks on the continental margin west of the Iberian peninsula: A test of the stretching model. EOS, 63:1276.

Sibuet, J.-C., and Mascle, J., 1978. Plate kinematic implications of Atlantic equatorial fracture zone trends: J. Geophys. Res., 83: 3401-3421.

Sibuet, J.-C., and Veyrat-Peinet, B., 1980. Gravimetric model of the Atlantic equatorial fracture zones. J. Geophys. Res., 85:943-954.

Siesser, W. G., 1980. Late Miocene origin of the Benguela Upwelling system off northern Namibia. Science, 208:283-285.

Simpson, E. S. W., 1970. The geology of the SW African continental margin: A review. The Geology of the East Atlantic Continental Margin (SCOR/IUGS symposium on East Atlantic continental margins): London (Instit. Geol. Sci. Rept.), 70(16):153-170.

Simpson, E. S. W., 1981. Bathymetric chart of the southeast Atlantic and southwest Indian oceans: Cape Town, South Africa (Cape Town University, Dept. Geology), chart 124A.

South Africa Geological Survey, 1963. Geological map of South West Africa showing mineral occurrences and gravity contours (Bouguer anomalies). Pretoria, South Africa.

Vail, P. R., Mitchum, R. M., and Thompson, S., III, 1977. Seismic stratigraphy and global changes of sea-level, part 3: Relative changes of sea level from coastal onlap. Am. Assoc. Pet. Geol. Mem., 26:63-81.

van der Linden, W. J. M., 1980. Walvis Ridge, A piece of Africa? Geology, 8:417-421.

Wilson, J. T., 1965. Submarine fracture zones, aseismic ridges and the ICSU line proposed western margin of the East Pacific Rise. $\mathrm{Na}$ ture, 207:907-911.

Date of Initial Receipt: June 20, 1983 